Article

\title{
Interactive Effects of Grafting Techniques and Scion-Rootstocks Combinations on Vegetative Growth, Yield and Quality of Cucumber (Cucumis sativus L.)
}

\author{
Rana Shahzad Noor ${ }^{1,2}{ }^{\oplus}$, Zhi Wang ${ }^{1}\left(\mathbb{D}\right.$, Muhammad Umair ${ }^{2}{ }^{-}$, Muhammad Yaseen ${ }^{3}$, \\ Muhammad Ameen ${ }^{4}$, Shoaib-Ur Rehman ${ }^{5}$, Muzammil Usman Khan ${ }^{5}$, Muhammad Imran ${ }^{6}$ (D), \\ Waqar Ahmed ${ }^{7}$ and Yong Sun ${ }^{1, *}$ \\ 1 Department of Agriculture, Biological, Environment and Energy Engineering, College of Engineering, \\ Northeast Agricultural University, Harbin 150030, China; engr.rsnoor@uaar.edu.pk (R.S.N.); \\ wangzhi@neau.edu.cn (Z.W.) \\ 2 Faculty of Agricultural Engineering \& Technology, PMAS-Arid Agriculture University, \\ Rawalpindi 46000, Pakistan; umairkpr@uaar.edu.pk \\ 3 Department of Agricultural Extension, College of Agriculture, University of Sargodha, \\ Sargodha 40100, Pakistan; yaseen.baksh@uos.edu.pk \\ 4 College of Engineering, Nanjing Agricultural University, Nanjing 210031, China; ameenkhan114@yahoo.com \\ 5 Institute of Horticultural Sciences, University of Agriculture, Faisalabad 38040, Pakistan; \\ shoaibhort@gmail.com (S.-U.R.); khancoca0@gmail.com (M.U.K.) \\ 6 Faculty of Water Resources and Hydroelectric Engineering, Xi'an University of Technology, \\ Xi'an 710048, China; 180414001@stu.xaut.edu.cn \\ 7 Key Laboratory of Soybean Biology, Chinese Ministry of Education, Northeast Agricultural University, \\ Harbin 150030, China; khuhrowaqar@gmail.com \\ * Correspondence: sunyong@neau.edu.cn; Tel.: +86-138-36145034
}

Received: 13 April 2019; Accepted: 31 May 2019; Published: 5 June 2019

\begin{abstract}
The density of herbaceous crops creates a suitable environment to produce pathogens in the soil that intensify the attack of pathogens traditionally controlled by disinfectant, which are mostly prohibited and unlisted because of their toxicity. Grafting is an alternative technique to enhance abiotic stress tolerance and reduce root diseases due to soil-borne pathogens, thus enhancing crop production. This research study was conducted during the crop season of 2017 and 2018 in order to investigate the interactive effect of different grafting techniques of hybrid scion onto local rootstocks on plants survival, plant phenological growth, fruit yield and fruit quality under a controlled environment. The hybrid cucumber was also planted self-rooted. The cucumber (Cucumis sativus L.) cv. Kalaam $\mathrm{F}_{1}$, Syngenta was grafted onto four local cucurbitaceous rootstocks; ridge gourd (Luffa operculate Cogn.), bitter gourd (Momordica charantia L.), pumpkin (Cucurbita pepo L.), bottle gourd (Lagenaria siceraria (Molina) Standl.) using splice grafting, tongue approach, single cotyledon and hole insertion grafting techniques and self-rooted hybrid cucumber under greenhouse conditions. The experimental results indicated that all local cucurbitaceous rootstocks showed a high compatibility with hybrid cucumber scion in the splice grafting method compared to other grafting and non-grafted methods. Lagenaria siceraria rootstocks were found highly compatible with cucumber cv Kalaam scion which gave significantly maximum plant survival rates (95\%) due to high sap contents, high SPAD value, better vegetative growth and maximum fruit yield when compared with other rootstocks by employing the splice grafting method followed by tongue approach, single cotyledon and hole insertion grafting while the fruit quality of all rootstocks was observed to be similar. The non-grafted cucumber $\mathrm{cv}$. Kalaam $\mathrm{F}_{1}$ showed significant results of plant vegetative growth, fruit development and fruit quality and encountered grafting methods while the lowest result were associated with the hole insertion grafting method in all scion/rootstock combinations.
\end{abstract}


The grafted plants have no significant effect on cucumber fruit dry matter and fruit quality while the fruit mineral compositions $(\mathrm{N}, \mathrm{P}, \mathrm{K}, \mathrm{Ca}$ and $\mathrm{Mg}$ ) were higher among grafted and non-grafted plant fruits. The results indicate that grafting hybrid cucumber onto four local cucurbitaceous rootstocks influenced growth, yield and fruit quality. Grafting can be alternative and control measure for soil-borne disease and to enhance cucumber production.

Keywords: cucumber; grafting techniques; rootstock-scion; soil-borne disease; resistant; tolerant crop growth; fruit yield; fruit quality

\section{Introduction}

Grafting entails a deliberate combination of parts of different plants of the same species by which vascular continuity is established [1]. The crown of the plant (Scion) adheres to the root part of the plant (rootstock) resulting in composite plant growth and development of a single plant (graft) [2]. The callus related to parenchyma cells develops from the plant tissue of the rootstock and scion around the joint portion to develop vascular connection [3]. Grafting is a horticultural technique applied in the sustainable agricultural practice for the protection of cucurbitaceous crops from soil-borne pathogens, nematodes, soil $\mathrm{pH}$ and salinity. This problem has been globally important since 2005 when the application of methyl bromide was prohibited [4]. The rapid multiplication of soil-borne pathogens and nematodes is due to the intensive use of soil and absence of crop rotation. This affects vegetable growth particularly under greenhouse conditions [5]. It is a big challenge to reduce the impact of soil pathogens for a sustainable agriculture production system [6] and monoculture is more susceptible than a diversified agricultural system [7]. The rootstocks resistant for nematodes are not available; nematodes cause $11 \%$ annual average yield loss [8].

Grafting has become a technique with a high potential to improve the efficiency of modern and intelligent vegetable cultivation, and indicates adoptability and resistance under different stress situations [9]. The grafting of plants is carried out to develop tolerance against temperature variation, salt stress and heavy metal contents in the soil. The grafting scion on appropriate local rootstocks can medicate these issues [10-12]. The structural and biological development of graft between scion and rootstock has been studied and three basic phases have been observed, namely: combining scion and rootstock, callus creation around the joint and establishing continuity at joint through vascular re-differentiation $[1,3,13,14]$. These discussed events determine the success of the scion-rootstock combination, considering the role of plant growth hormones (auxin) in the grafting technique [15]. The graft may grow through the wound healing mechanism and formation of conductive vessels [16]. Therefore, the formation of vascular connection represents the last and most critical stage in wound healing because after healing, the transportation of water and solute start from the rootstock to the scion and the graft union develops a strength $[13,17]$. The time required for the completion of grafting stages is a little unpredictable [17] because an appropriate method for the assessment of development in grafting does not exist [18]. However, the development can be predicted by destructive and non-destructive methods, including the visual determination of graft [19], thermal camera image [19], cutting graft vertically at union to observe vascular system [20], electrical resistance measurement from scion to rootstock [19] asses tensile strength at scion-rootstock union [21,22], disruptive evaluation of hydraulic connection [23] and the nuclear magnetic resonance (NMR) method to show water flux inside vessels [23].

Cucurbitaceous crops are mostly grown during the warm season (greenhouse conditions, $21^{\circ} \mathrm{C}$ to $32{ }^{\circ} \mathrm{C}$ ). The temperature below $16^{\circ} \mathrm{C}$ is not suitable for the germination of cucumber seeds [24]. Cucumber is grown during the warm season when vegetables produce good crops when grown under protection [24]. The above discussed problems severely influence the area and production under greenhouse conditions [25]. The grafting of scion on local rootstocks is the most effective solution to 
this problem. Cucumber (Cucumis sativus L.) grafted on different cucurbitaceous crop rootstocks are Cucurbita maxima Duchesne, C. moschata, C. ficifilia, Lagenaria spp., Luffa spp. [26-28]. The selective method of grafting considerably depends upon crop type, grower decision and experience, as well as facilities availability [29]. Splice grafting [30,31], tongue grafting [32], single cotyledon [4,33] and hole insertion grafting $[19,34]$. Several studies indicated that the grafting technique showed productive findings such as increase growth, yield and tolerance against stress conditions [35-37]. These plant characteristics majorly linked with genotype of rootstock particularly plant growth and yield effected by rootstock $[37,38]$. The grafting of cucumber crop on different rootstock reduces precocity but the total yield significantly increased as compared with non-grafted plants [39].

The grafting had some undesirable effects such as deterioration in taste, changes in the fruit color, bigger fruit size. The grafting also resulted the increment in fructose content and sweetness of cucumber which indicates the significance of rootstock [40]. The collar size of grafted plants varies depending upon rootstock. Frequently, the diameter of the collar of the grafted plants is higher [39]. The concerning, uncertainties regarding scion-rootstock and environmental instructions. The best selection for rootstock based on production area, rootstock species and scion cultivars used under different conditions [41]. The combination of rootstock and scion must be carefully selected according to the specific calamitic and soil condition [42]. The adequate rootstock-scion combination could help to regulate the soil borne diseases, increase yield and improve fruit quality.

This motivates us to carry out a more detailed study of these significant parameters such as yield, earliness, taste and some fruit sensory characteristics of grafted cucumber plants on different cucurbit rootstocks. This study was carried out to investigate the effect of grafting a hybrid cucumber scion onto four local cucurbitaceous rootstocks by four different grafting technique under greenhouse conditions on plants survival, plant phenological growth, fruit yield and fruit quality in order to establish the most tolerant scion-rootstock combination and favorable method for cucumber grafting. The hybrid scion cucumber cv Kalaam $\mathrm{F}_{1}$ and four rootstocks, namely ridge gourd (Luffa operculata), bitter gourd (Momordica charantia), pumpkin (Cucurbita pepo), bottle gourd (Lagenaria siceraria) were used as scion-rootstock combinations in order to check the compatibility of tongue grafting, splice grafting, single cotyledon grafting and hole insertion grafting.

\section{Materials and Methods}

This experimental study was conducted during the crop season of 2017 and 2018 at Floriculture Research Station, University of Agriculture, Faisalabad to evaluate the compatibility and suitability of grafting techniques for hybrid cucumber $\mathrm{cv}$. Kalaam $\mathrm{F}_{1}$ scion grafted onto four local cucurbitaceous rootstocks (Pumpkin, Ridge gourd, Bottle Gourd and Bitter gourd) under greenhouse conditions (Temperature $28^{\circ} \mathrm{C}$ and $90 \%$ humidity). Screening and determining the resistant and tolerant rootstock against soil pathogenic characteristics were performed.

\subsection{Grafting Plant Materials}

The hybrid cucumber $\mathrm{cv}$. Kalaam $\mathrm{F}_{1}$ from Syngenta seed company was used as a scion. Four local rootstocks from cucurbitaceous species; ridge gourd (Luffa operculata), bitter gourd (Momordica charantia), pumpkin (Cucurbita pepo), bottle gourd (Lagenaria siceraria) were used as shown in Table 1.

\subsection{Nursery of Scion and Rootstocks}

Cucumber cv Kalaam $\mathrm{F}_{1}$ scion were grafted on four local cucurbitaceous rootstocks by tongue grafting, splice grafting, single cotyledon grafting and hole insertion grafting. Scions were sown in a nursery greenhouse on 25th and 28th of July in 2017 and 2018 in a 200-hole tray and rootstocks were grown in seedling trays with 128 cells $(280 \times 540 \times 40 \mathrm{~mm})$. The seeds of four different rootstocks named as Luffa operculata, Momordica charantia, Cucurbita pepo and Lagenaria siceraria were sown after five days of scion seed sowing. Peat moss and vermiculite ratio 1:1 (v/v) was used as growing media because it sustained better equilibrium of moisture and air which was best for seedlings. $100 \mathrm{~g}$ ammonium 
sulphate, $150 \mathrm{~g}$ potassium sulphate, $400 \mathrm{~g}$ calcium superphosphate, $50 \mathrm{~mL}$ nutrient solution and $50 \mathrm{~g}$ of fungicide were mixed for each $50 \mathrm{~kg}$ of peat moss. The characteristics of the growing media before seed sowing were: $\mathrm{pH}-6.7$, electrical conductivity EC- $0.14 \mathrm{mS} \mathrm{cm}^{-1}, \mathrm{NO}_{3}-15 \mathrm{mg} \mathrm{dm}^{3}, \mathrm{P}-4 \mathrm{mg} \mathrm{dm}^{3}$, $\mathrm{K}-31 \mathrm{mg} \mathrm{dm}{ }^{3}, \mathrm{Ca}-28 \mathrm{mg} \mathrm{dm}^{3}, \mathrm{Mg}-17 \mathrm{mg} \mathrm{dm}^{3}$ and total nitrogen $0.25 \%$ [43]. Nitrogen, phosphate and potassium fertilizer were also applied. The seeds were sown under $28{ }^{\circ} \mathrm{C}$ mean temperature and $80 \%$ relative humidity. The 400 scion plants and 400 rootstocks (100 for each rootstock) were prepared and 200 plants (100 scion and 100 rootstocks) were used in each grafting technique. The experimental treatments, their levels and replication were presented in Table 1 . The scion-rootstock were shifted into plastic pots of $8 \mathrm{~cm}$ diameter with the same growing media. Before grafting, a laminar flow UV light was used to kill the microbes in the working place [43].

\subsection{Grafting Techniques and Procedure}

The four grafting techniques used were splice grafting, tongue grafting, single cotyledon and hole insertion grafting. The different aged seedlings were grafted under the different grafting methods. Grafting method required selection of seedlings that mainly based on its stem diameter. Each grafting technique was applied on 100 scion and 100 rootstocks ( 25 for each rootstock) with four treatments and five replications.

The scion and rootstock plants were taken out from the seedling tray. The grafting was performed and then the plants were shifted into disposable plastic pots with same growing media and characteristics. In tongue grafting technique (TAG), the plants were 17 and 15 days old (4 mm stem diameter) taken for root-stock and scion gave the best diameter match. The downward and upward slanting cut were made on scion stock and rootstock respectively [32,44,45]. In splice grafting, the 15 day old plants were preferably matched stem diameter that can fits with each other were best fits for that graft union. The rootstock and scion stock were cut slanted at $35^{\circ}-45^{\circ}$ downward and upward respectively $[33,34]$. The 14 days rootstock and 13 days scion stock fit best for this graft combination in single cotyledon grafting method. The scion was grafted on the stem of rootstock plant [36,37]. The hybrid cucumber scions of 13 days and pumpkin rootstocks of 10 days were best match for grafting. Rootstock was removed just above the false leaf, and the sharpened scion was inserted in it after making a hole between the false leaf interjections with the help of small narrow sterilized wooden sticks $[20,38]$. The union point was sealed with aluminum wrap and grafting clips. The plastic pots were enveloped with transparent plastic sheet in order to maintain the humidity level around the graft. The plastic sheet was cut from top side after three days in order to allow vertical growth. Grafting plants healing begun after five days and plastic sheet was taken off completely after six days. Plants were supplied water and fertilizer accordingly.

The plants were kept in screen house for eight days after twelve days of grafting. This whole procedure took 30-35 days after transplanting. Transplantation of grafted plants was performed on September 9th and 12th, 2017 and 2018. The grafted plants rows were of $10 \mathrm{~m}$ in length and $1.2 \mathrm{~m}$ in width with $0.5 \mathrm{~m}$ distance between plants. Each single treatment consisted of twenty (20) plants in a row. The plants were transplanted keeping union of graft above the soil surface to prevent the development of roots from graft union that may cause infection and plant wilting. The conventional agricultural practices were adopted during the entire cucumber crop production. The cucumber fruit was harvest after 70 days from grafting ( 35 days after transplanting) and then cucumber fruit was harvested with two days interval. The following parameters were studied during this research study.

\subsection{Studied Characteristics}

The plant and fruit growth characteristics were studied to evaluate the compatibility of different grafting techniques applied on four local cucurbitaceous rootstocks and one hybrid cucumber scion. 


\subsubsection{Plant Vegetative Growth}

The plant sustainability after grafting was measured till 30 days after grafting and the measurements were taken for plant vegetative growth 75 days after transplanting. Three plants were randomly selected from each treatment. The mean leaf area $\left(\mathrm{cm}^{2}\right)$ was measured through fresh weight method. The collected leaves were cleaned and weighted $0.001 \mathrm{~g}$. The 20 disks with known weight were taken and the area of each disk was $1.0 \mathrm{~cm}^{2}$.

$$
\text { Leaf area }\left(\mathrm{cm}^{2}\right)=\frac{\text { fresh weight of leaf No.10 }}{\text { fresh weight of } 20 \text { diske }} \times 20 \times \text { area of disk }
$$

The other plant vegetative parameter measured number of leaves, plant height $(\mathrm{cm})$, shoot length $(\mathrm{cm})$, stem diameter/thickness $(\mathrm{cm})$, number of plant branches and chlorophyll content/SPAD values were using SPAD-501 (leaf chlorophyll meter) to estimate the leaves pigments or green color of leaves of 5th leaf (fully expanded) from the top of canopy [46]. At flowering stage flowering time (days), fruiting harvesting time (days) and survival rates (\%) were observed. The plant survival rates and mortality were observed after 12 days from the grating by counting the number of plants wilted. The survival rates were recorded till harvesting stage.

\subsubsection{Fruit Growth and Quality Analysis}

The parameters studied for fruit growth and quality were total number of fruits/plants, fruit weight per cucumber (g), fruit shape index, total soluble solids (\%), fruit dry matter (\%), fruit chemical contents, mineral composition and fruit fresh weight $(\mathrm{g})$, length of fruit $(\mathrm{cm}) \&$ fruit diameter $(\mathrm{cm})$.

The fruit shape index was a ratio between cucumber fruit length and diameter. Total soluble solids (T.S.S \%) in fruit juice was measured using hand refractometer. Five samples were analyzed from each scion-rootstock combination [47]. Fruit dry matter (\%) was measured through drying $100 \mathrm{~g}$ of fresh fruit weight in an oven at $70{ }^{\circ} \mathrm{C}$ till no further weight reduction condition reached. The contents of ascorbic acid in all grafted and non-grafted fruit were measured by 2,6-dichlorophenol-indophenol method [48]. Bradford G-250 reagent was used to calculate the soluble protein [49] while ninhydrin technique was used to measure total amino acids [50]. Soluble sugar was calculated by anthrone [51]. Fruit mineral composition by the atomic absorption spectrometer (Varian spectra 220) to calculate after dry fruit ashes $\left(550^{\circ} \mathrm{C}\right)$ and mixed in $1 \mathrm{~N} \mathrm{HCl}$. The $\mathrm{N}$ and $\mathrm{P}$ were observed by Kjeldahl technique and vanado-molybdate phosphoric yellow color method. The fruit fresh weight $(\mathrm{g})$, fruit length $(\mathrm{cm})$ and fruit diameter $(\mathrm{cm})$ were measured right after the first day of fruit development to harvesting (day 1-9).

\subsection{Data Processing and Experimental Design}

The experimental data collected were than analyzed statistically using one-way analysis of variance (ANOVA) to evaluate the level of significance. Tukey HSD at 5\% level of significance was applied to check the significant difference between values of studied parameter. The complete statistical analysis was performed using Minitab 17 statistical software (Minitab Pty Ltd., Sydney, Australia).

Table 1. Treatments, their level and replication for different grafting techniques.

\begin{tabular}{|c|c|c|}
\hline Grafting Technique & Cucurbitaceous Crop & Treatment Description (Scion-Rootstock) \\
\hline \multirow{2}{*}{$\begin{array}{c}\mathrm{G}_{1}=\text { Tongue grafting } \\
\mathrm{G}_{2}=\text { Splice grafting } \\
\mathrm{G}_{3}=\text { Single cotyledon grafting } \\
\mathrm{G}_{4}=\text { Hole insertion } \\
\text { Grafting } \\
\mathrm{G}_{\mathrm{n}}=\text { Non-grafted }\end{array}$} & \multirow{2}{*}{$\begin{array}{c}\text { Scion; } \\
\text { Cucumber cv. Kalaam } F_{1} \\
\text { Rootstock; } \\
\text { Ridge gourd (Luffa operculata) } \\
\text { Bitter gourd (Momordica charantia) } \\
\text { Pumpkin (Cucurbita pepo) } \\
\text { Bottle gourd (Lagenaria siceraria) }\end{array}$} & $\begin{array}{c}\mathrm{T}_{1}=\text { Cucumber-Ridge gourd } \\
\mathrm{T}_{2}=\text { Cucumber-Bitter gourd } \\
\mathrm{T}_{3}=\text { Cucumber-Pumpkin } \\
\mathrm{T}_{4}=\text { Cucumber-Bottle gourd } \\
\mathrm{T}_{\mathrm{C}}=\text { Kalam } \mathrm{F}_{1} \text { (real rooted) }\end{array}$ \\
\hline & & $\begin{array}{ll} & \mathrm{R}_{1} \\
& \mathrm{R}_{2} \\
& \mathrm{R}_{3} \\
& \mathrm{R}_{4} \\
& \mathrm{R}_{5}\end{array}$ \\
\hline
\end{tabular}




\section{Results and Discussion}

\subsection{Plant Vegetative Growth}

The results of vegetative growth and survival rate of cucumber (Cucumis sativus) plants grafted on different cucurbitaceous rootstocks were observed after 15 and 30 days of grafting in two crop season 2017 and 2018. The leaf area, number of leaves and SPAD values after the first 15 days of grafting, during both crop seasons of 2017 and 2018, were observed in all combination of cucumber (Kalaam $\mathrm{F}_{1}$ ) scion and four local rootstocks; ridge gourd, bitter gourd, pumpkin and bottle gourd were presented in Figure 1. The mean leaf area $\left(\mathrm{cm}^{2}\right)$ of cucumber $\mathrm{cv}$. Kalaam $\mathrm{F}_{1}$ was found significantly maximum during both crop seasons 2017 and 2018 when grafted onto bottle gourd rootstock followed by ridge gourd, bitter gourd and pumpkin rootstock with the splice grafting $(36.10,37.65)$, single cotyledon grafting $(32.40,33.23)$, tongue grafting $(28.23,29.98)$ and hole insertion grafting $(25.80,26.13)$ respectively. The leaf area $(21.43,22.70)$ was found non-significant in non-grafting cucumber $\mathrm{cv}$. Kalaam $F_{1}$. The results observed in both seasons didn't show any significant difference. The plants with bottle gourd rootstocks showed significantly maximum five plant leaves in tongue grafting, splice grafting and single cotyledon grafting during both crop seasons. The real rooted plants produced four plant leaves while the lowest figures were associated with pumpkin rootstock. Figure 1 illustrates that the SPAD values (chlorophyll content) were found significantly different in all grafting techniques and non-grafted plants during the vegetative growth stage. The splice grafting technique gave optimum results of chlorophyll content than other grafting methods. The significantly different SPAD values $(49.31,46.6)$ were found in cucumber $\mathrm{cv}$. Kalaam $\mathrm{F}_{1}$ grafted onto bottle gourd with splice grafting during 2017 and 2018 crop season respectively. The SPAD values in plant leaf of real rooted Kalaam $\mathrm{F}_{1}$ and pumpkin rootstock in hole insertion grafting method were statistically non-significant.

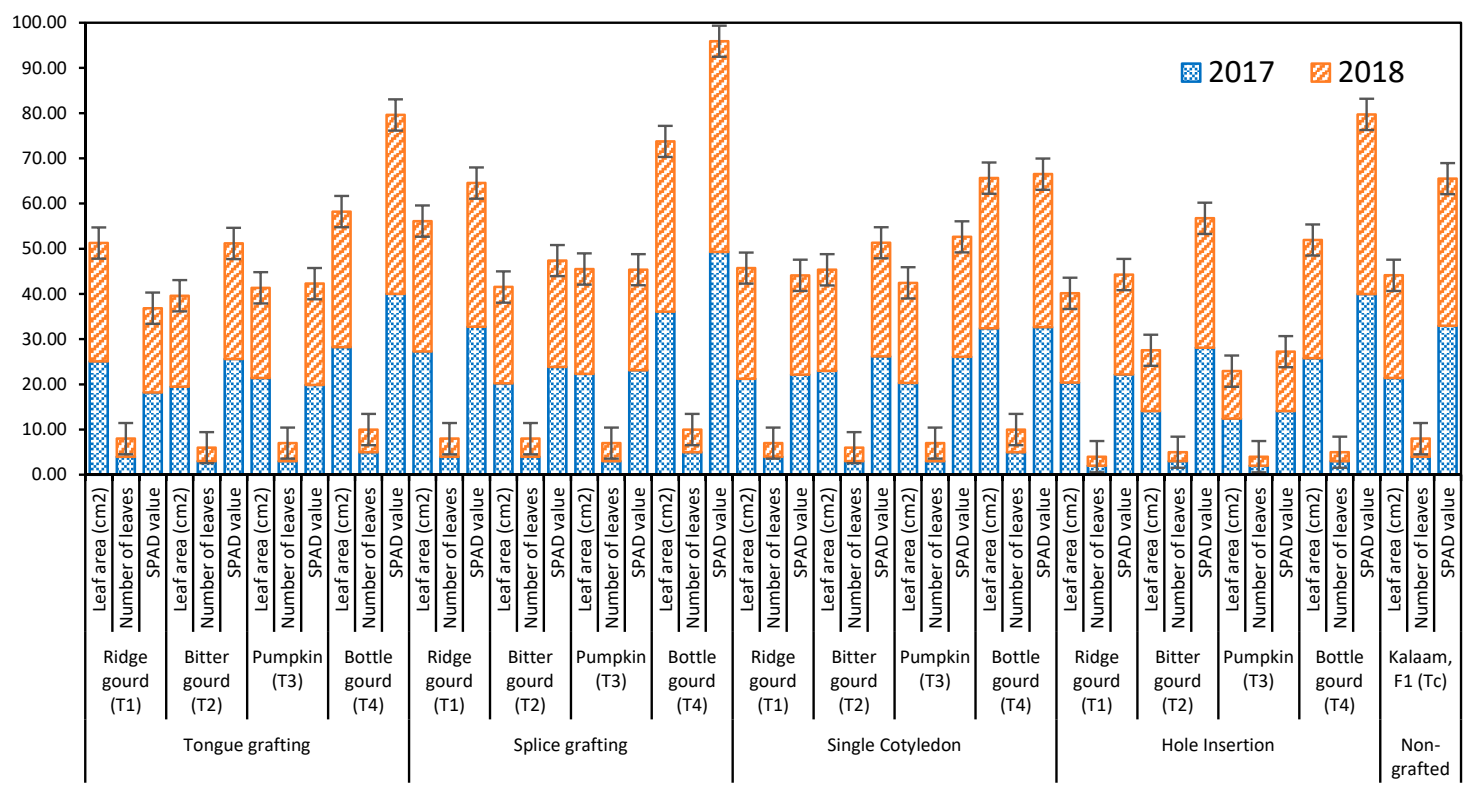

Figure 1. Evaluating the effect of Scion/rootstocks combinations (grafting) on vegetative growth of Cucumber fruit after 15 days during crop season 2017 and 2018.

After 30 days, the bottle gourd rootstock in splice grafting showed significantly higher mean leaf area $\left(82.40,85.28 \mathrm{~cm}^{2}\right)$, number of leaves $(8,8)$ and SPAD contents $(49.31,56.22)$ during both crop season 2017 and 2018 respectively as shown in Figure 2. The real rooted cucumber didn't show significant difference of leaf area $\left(40.95,44.65 \mathrm{~cm}^{2}\right)$, number of leaves $(7,7)$ and SPAD value $(39.98,42.8)$ during crop season of 2017 and 2018 while the rootstocks in hole insertion grafting showed non-significant results. 
It could be found that the SPAD values and chlorophyll content have a strong correlation [42] and the combinations of scion/rootstocks had significantly affected the vegetative growth of cucumber [52].

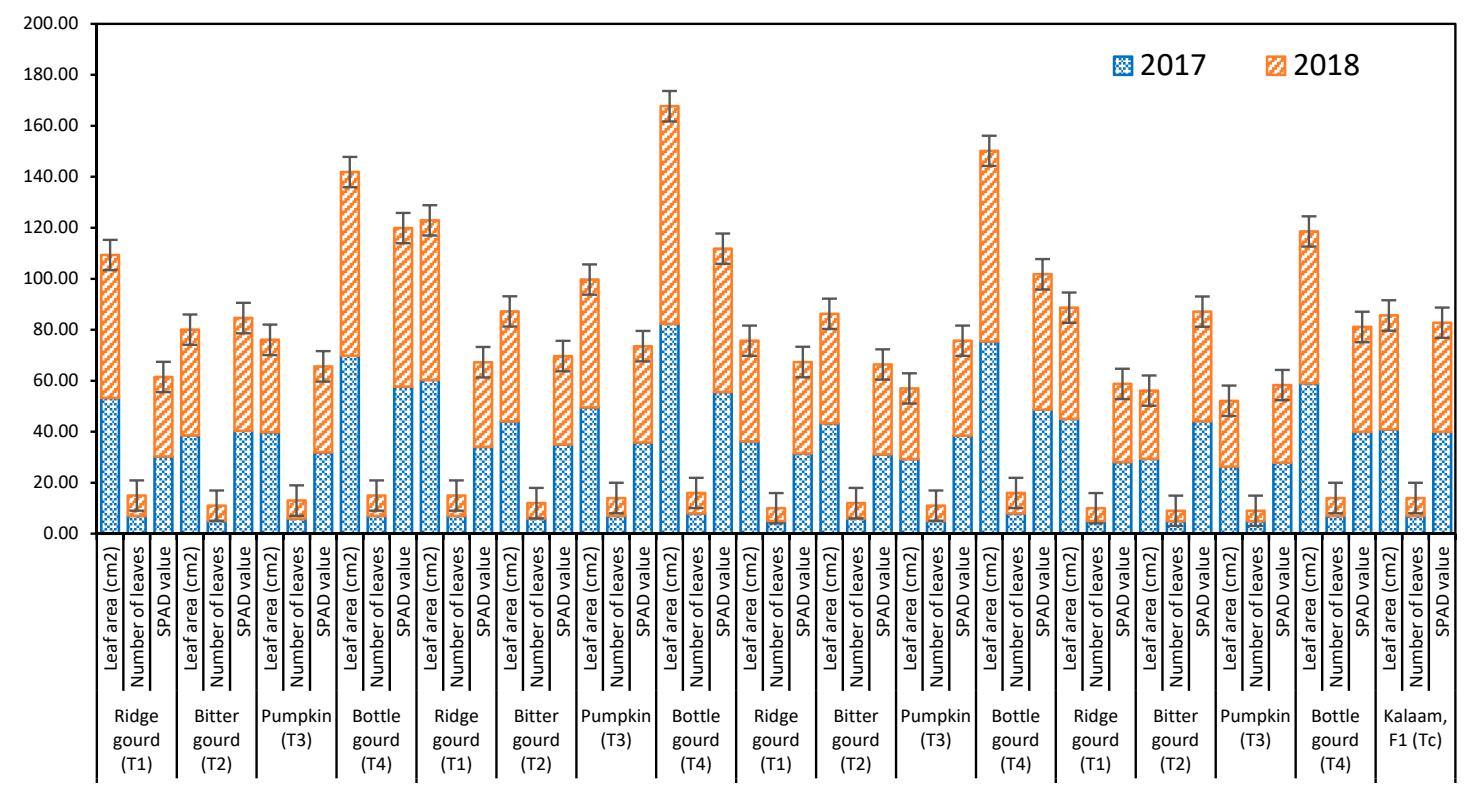

Figure 2. Evaluating the effect of Scion/rootstocks combinations (grafting) on vegetative growth of Cucumber fruit after 30 days during crop season 2017 and 2018.

Table 2 indicates plant mortality and the percentage of plant survival in the real rooted and grafted treatment of hybrid cucumber cv. Kalaam $\mathrm{F}_{1}$ grafted on four local cucurbitaceous rootstocks (ridge gourd, bitter gourd, pumpkin and bottle gourd) with different grafting techniques during the 2017 and 2018 crop growing seasons. The statistical analysis presented in Table 2 shows that pumpkin rootstock in the hole insertion grafting method had a lower plant survival (42.00 \pm 0.81 and $44.00 \pm 1.29)$ in the 2017 and 2018 seasons respectively. These results showed unsuitability of hybrid Kalam $\mathrm{F}_{1}$ with local rootstock. The significantly maximum plant survival rate of $(96.00 \pm 2.77)$ was obtained when grafted plants onto bottle gourd $\left(\mathrm{T}_{4}\right)$ in splice grafting during the first crop season, while in the second crop season bottle gourd $\left(T_{4}\right)$ and ridge gourd $\left(T_{1}\right)$ showed the same $(95.00 \pm 0.55)$ survival rates of grafted plants. Ridge gourd $\left(\mathrm{T}_{1}\right)$ and bitter gourd $\left(\mathrm{T}_{2}\right)$ in tongue grafting $\left(\mathrm{G}_{1}\right)$ and real rooted Kalaam, $\mathrm{F}_{1}\left(\mathrm{~T}_{\mathrm{c}}\right)$ didn't show any significant difference during first growing season while, in second crop season ridge gourd $\left(\mathrm{T}_{1}\right)$ and bottle gourd $\left(\mathrm{T}_{4}\right)$ in tongue grafting $\left(\mathrm{G}_{1}\right)$ and non-grafted Kalaam, $\mathrm{F}_{1}\left(\mathrm{~T}_{\mathrm{c}}\right)$ didn't show any significant difference in cucumber plants survival. The rootstocks under single cotyledon grafting method show significantly different results for plants survival. These results agreed with [53] who reported that the survival rate of cucumber plants increased under different grafting techniques.

The shoot length, plant height and stem diameter of cucumber (Cucumis sativus) plants grafted onto four local cucurbitaceous rootstocks with different grafting methods were presented in Figure 3. The bottle gourd rootstock had significant shoot length $(\mathrm{cm})$ in tongue grafting $(13.50,13.30)$, splice grafting $(12.20,12.10)$ and single cotyledon grafting $(11.34,11.28)$ after first 15 days of grafting during 2017 and 2018 respectively while the hole insertion grafting showed non-significant results $(4.15,4.1)$ onto ridge gourd. The real rooted plant has $(9.0,9.20)$ shoot lengths. The plants with bottle gourd rootstock developed a significantly thick plant stem $(0.19,0.18 \mathrm{~cm})$ in splice grafting and didn't show any significant difference of stem diameter during season 2017 and 2018 respectively. The real rooted hybrid cucumber had $(0.15$ and $0.16 \mathrm{~cm})$ stem diameter after first 15 days of 2017 and 2018 seasons. In tongue grafting and single cotyledon grafting, the bottle gourd showed significant plant height $(15.34,15.50 \mathrm{~cm}),(16.10,15.73 \mathrm{~cm})$ while the pumpkin rootstock in hole insertion grafting had non-significant $(6.55,6.49 \mathrm{~cm})$ plant height during 2017 and 2018 respectively. 
Table 2. Effect of grafting hybrid cucumber $\mathrm{cv}$. Kalaam $\mathrm{F}_{1}$ onto local rootstocks on plant survival rate.

\begin{tabular}{|c|c|c|c|c|c|c|c|c|}
\hline \multirow{3}{*}{$\begin{array}{l}\text { Grafting } \\
\text { Technique }\end{array}$} & \multirow{3}{*}{ Rootstock Cultivar } & \multirow{3}{*}{$\begin{array}{c}\text { Number of } \\
\text { Grafted Plants }\end{array}$} & \multicolumn{3}{|c|}{2017} & \multicolumn{3}{|c|}{2018} \\
\hline & & & \multicolumn{2}{|c|}{ Mortality (\%) } & \multirow[t]{2}{*}{ Plants Survival (\%) } & \multicolumn{2}{|c|}{ Mortality (\%) } & \multirow[t]{2}{*}{ Plants Survival (\%) } \\
\hline & & & Day, 15 & Day, 30 & & Day, 15 & Day, 30 & \\
\hline \multirow{4}{*}{$\begin{array}{l}\text { Tongue grafting } \\
\qquad\left(\mathrm{G}_{1}\right)\end{array}$} & Ridge gourd $\left(\mathrm{T}_{1}\right)$ & 100 & $10.00 \pm 0.12 f$ & $18.00 \pm 0.53 f$ & $82.00 \pm 1.08 b c$ & $8.00 \pm 0.15 f$ & $17.00 \pm 0.27 \mathrm{hi}$ & $83.00 \pm 2.31 \mathrm{~cd}$ \\
\hline & Bitter gourd $\left(\mathrm{T}_{2}\right)$ & 100 & $13.00 \pm 0.12 \mathrm{e}$ & $20.00 \pm 0.29 \mathrm{ef}$ & $80.00 \pm 1.60 \mathrm{bc}$ & $14.00 \pm 0.24 \mathrm{~d}$ & $19.00 \pm 0.28 \mathrm{~h}$ & $81.00 \pm 0.75 \mathrm{cde}$ \\
\hline & Pumpkin $\left(\mathrm{T}_{3}\right)$ & 100 & $20.00 \pm 0.36 c$ & $35.00 \pm 1.02 b$ & $65.00 \pm 1.17 f$ & $19.00 \pm 0.55 c$ & $34.00 \pm 0.48 c$ & $66.00 \pm 2.13 \mathrm{hi}$ \\
\hline & Bottle gourd $\left(\mathrm{T}_{4}\right)$ & 100 & $7.00 \pm 0.13 \mathrm{~g}$ & $17.00 \pm 0.42 f$ & $83.00 \pm 1.95 b$ & $8.00 \pm 0.12 \mathrm{f}$ & $16.00 \pm 0.49 \mathrm{ij}$ & $84.00 \pm 0.91 \mathrm{~cd}$ \\
\hline \multirow{3}{*}{$\begin{array}{l}\text { Splice grafting } \\
\qquad\left(\mathrm{G}_{2}\right)\end{array}$} & Ridge gourd $\left(\mathrm{T}_{1}\right)$ & 100 & $4.00 \pm 0.04 \mathrm{~h}$ & $7.00 \pm 0.08 \mathrm{gh}$ & $93.00 \pm 0.61 \mathrm{a}$ & $3.00 \pm 0.10 \mathrm{hi}$ & $5.00 \pm 0.05 k$ & $95.00 \pm 1.15 \mathrm{a}$ \\
\hline & Bitter gourd $\left(\mathrm{T}_{2}\right)$ & 100 & $3.00 \pm 0.04 h$ & $8.00 \pm 0.16 g$ & $92.00 \pm 1.22 \mathrm{a}$ & $2.00 \pm 0.05 \mathrm{i}$ & $7.00 \pm 0.18 \mathrm{k}$ & $93.00 \pm 1.49 \mathrm{ab}$ \\
\hline & Bottle gourd $\left(\mathrm{T}_{4}\right)$ & 100 & $3.00 \pm 0.07 \mathrm{~h}$ & $4.00 \pm 0.09 \mathrm{~h}$ & $96.00 \pm 2.77 \mathrm{a}$ & $4.00 \pm 0.10 \mathrm{gh}$ & $5.00 \pm 0.12 \mathrm{k}$ & $95.00 \pm 0.55 a$ \\
\hline \multirow{4}{*}{$\begin{array}{l}\text { Single Cotyledon } \\
\text { grafting }\left(\mathrm{G}_{3}\right)\end{array}$} & Ridge gourd $\left(\mathrm{T}_{1}\right)$ & 100 & $11.00 \pm 0.36 f$ & $22.00 \pm 0.57 \mathrm{e}$ & $78.00 \pm 1.41 \mathrm{bcd}$ & $9.00 \pm 0.22 f$ & $23.00 \pm 0.37 \mathrm{~g}$ & $77.00 \pm 1.66 \mathrm{def}$ \\
\hline & Bitter gourd $\left(\mathrm{T}_{2}\right)$ & 100 & $10.00 \pm 0.22 f$ & $26.00 \pm 0.28 \mathrm{~d}$ & $74.00 \pm 2.38 \mathrm{cde}$ & $9.00 \pm 0.13 \mathrm{f}$ & $26.00 \pm 0.38 \mathrm{f}$ & $74.00 \pm 1.18$ efg \\
\hline & Pumpkin $\left(\mathrm{T}_{3}\right)$ & 100 & $20.00 \pm 0.58 c$ & $37.00 \pm 0.90 \mathrm{~b}$ & $63.00 \pm 1.07 f$ & $22.00 \pm 0.65 b$ & $37.00 \pm 0.75 b$ & $63.00 \pm 1.57 i$ \\
\hline & Bottle gourd $\left(\mathrm{T}_{4}\right)$ & 100 & $17.00 \pm 0.51 \mathrm{~d}$ & $23.00 \pm 0.62$ de & $77.00 \pm 2.22 \mathrm{~b}-\mathrm{e}$ & $15.00 \pm 0.42 \mathrm{~d}$ & $22.00 \pm 0.57 \mathrm{~g}$ & $78.00 \pm 0.56 \mathrm{def}$ \\
\hline \multirow{4}{*}{$\begin{array}{c}\text { Hole Insertion } \\
\text { grafting }\left(\mathrm{G}_{4}\right)\end{array}$} & Ridge gourd $\left(\mathrm{T}_{1}\right)$ & 100 & $14.00 \pm 0.19 \mathrm{e}$ & $30.00 \pm 0.94 c$ & $70.00 \pm 2.27 \mathrm{def}$ & $11.00 \pm 0.13 \mathrm{e}$ & $28.00 \pm 0.10 \mathrm{ef}$ & $72.00 \pm 1.20 \mathrm{fgh}$ \\
\hline & Bitter gourd $\left(T_{2}\right)$ & 100 & $16.00 \pm 0.26 \mathrm{~d}$ & $31.00 \pm 0.33 c$ & $69.00 \pm 1.49 \mathrm{ef}$ & $14.00 \pm 0.44 \mathrm{~d}$ & $31.00 \pm 0.46 \mathrm{~d}$ & $69.00 \pm 1.83 \mathrm{ghi}$ \\
\hline & Pumpkin $\left(\mathrm{T}_{3}\right)$ & 100 & $32.00 \pm 0.34 a$ & $58.00 \pm 1.62 \mathrm{a}$ & $42.00 \pm 0.81 \mathrm{~g}$ & $29.00 \pm 0.78 a$ & $56.00 \pm 0.79 a$ & $44.00 \pm 1.29 j$ \\
\hline & Bottle gourd $\left(\mathrm{T}_{4}\right)$ & 100 & $22.00 \pm 0.52 b$ & $31.00 \pm 0.60 c$ & $69.00 \pm 0.44 \mathrm{ef}$ & $20.00 \pm 0.22 c$ & $29.00 \pm 0.86 \mathrm{de}$ & $71.00 \pm 0.53 \mathrm{fgh}$ \\
\hline
\end{tabular}

Means sharing same letters in a column are statistically non-significant $(p>0.05)$. 


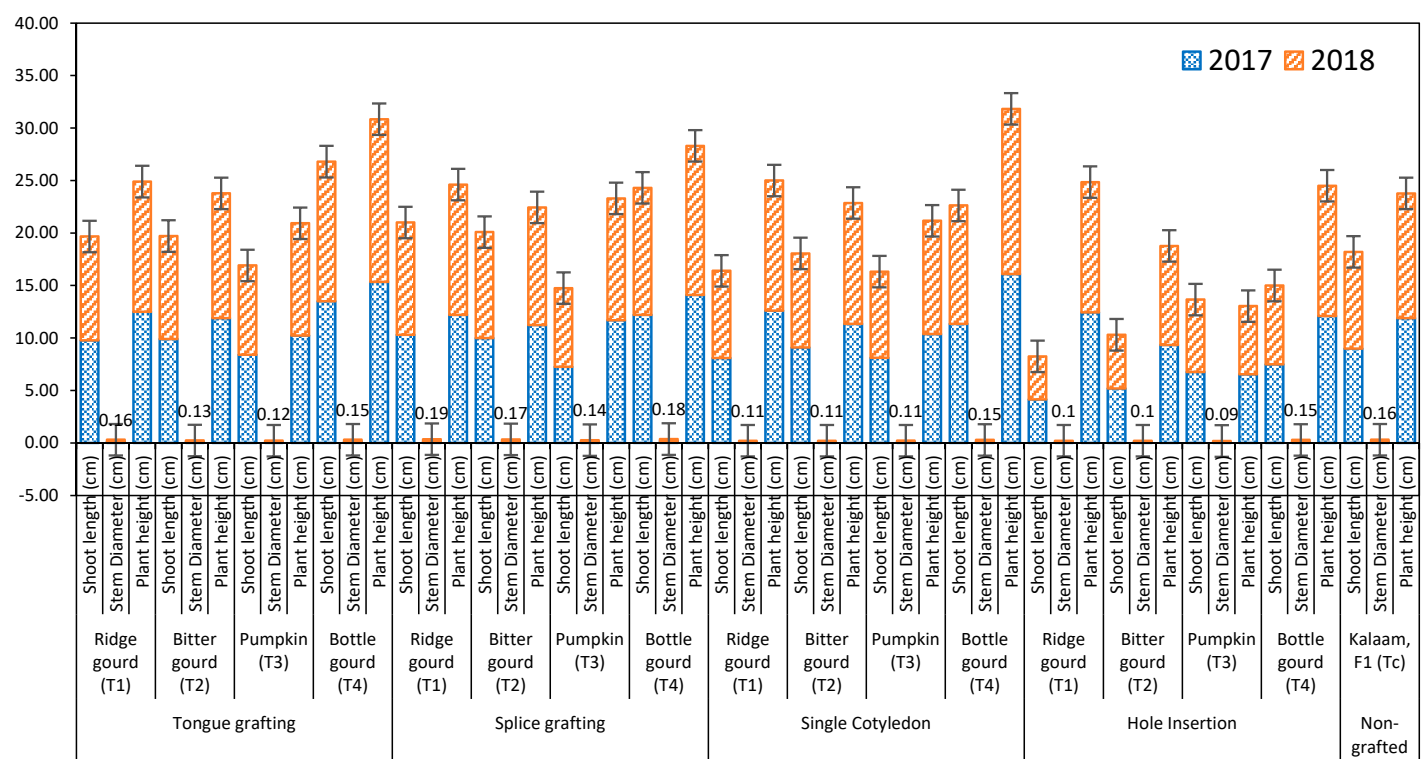

Figure 3. Effect of Scion/rootstocks combinations (grafting) on vegetative growth parameters of Cucumber fruit after 15 days during crop season 2017 and 2018.

Figure 4 presents shoot length, plant height and stem diameter of grafted cucumber (Cucumis sativus) plants onto cucurbitaceous rootstocks during the crop seasons of 2017 and 2018. After 30 days of grafting, The bottle gourd and ridge gourd rootstocks in splice grafting showed significant shoot length $(21.90,21.80 \mathrm{~cm})$ and $(20.98,21.10 \mathrm{~cm})$ while the hole insertion grafting showed non-significant results $(9.10,8.67 \mathrm{~cm})$ onto pumpkin rootstock after 30 days of grafting during 2017 and 2018 respectively. The non-grafted plants didn't show any significant difference. The plants with bottle gourd rootstock developed significantly thick plant stems $(0.37,0.38 \mathrm{~cm})$ in splice grafting. The bottle gourd in tongue grafting, ridge gourd and bitter gourd in splice grafting, bottle gourd in single cotyledon grafting and real rooted plants didn't show any significant difference of stem diameter during the seasons 2017 and 2018. The pumpkin rootstock in hole insertion grafting had $(0.15$ and $0.16 \mathrm{~cm}$ ) non-significant stem diameter after 30 days of grafting during both 2017 and 2018 crop seasons. In splice grafting and single cotyledon grafting, the bottle gourd showed significant plant height $(24.65,24.50 \mathrm{~cm}),(24.0,23.63 \mathrm{~cm})$. The bottle gourd rootstock in tongue grafting, ridge gourd in splice grafting, bottle gourd in single cotyledon and real rooted plants didn't show any significant change of plant height while the rest of the rootstocks showed non-significant plant height during 2017 and 2018 respectively.

The data in Table 3 indicate that the scion/rootstock combinations (grafting) promoted cucumber plant growth and significantly increased the vigor of grafts plants compared to real rooted hybrid cucumber during both 2017 and 2018 crop periods. That was shown in plant height $(\mathrm{cm})$, number of plant branches \& leaves, stem thickness/diameter (cm), flowering time (days) and first fruit harvesting time (days). Grafting cucumber cv. Kalaam $F_{1}$ on cucurbitaceous rootstock (Bottle gourd) produced significantly maximum plant height, stem diameter and No. of leaves \& nodes than rootstocks (Ridge gourd, Bitter gourd and Pumpkin). The sequence found between the grafting techniques was splice grafting, tongue grafting, single cotyledon grafting and hole insertion grafting. The splice grafting showed significantly maximum plant heights $(622.0 \pm 4.06$ and $619.0 \pm 4.58 \mathrm{~cm})$, number of leaves (194.0 \pm 6.32 and $183.0 \pm 4.62)$, number of branches (13.00 \pm 0.40 and $13.00 \pm 0.58)$ and stem diameter $(1.13 \pm 0.03$ and $1.10 \pm 0.03 \mathrm{~cm})$ for Lagenaria siceraria (bottle gourd) during crop season 2017 and 2018 respectively while, the lowest values were associated with pumpkin rootstock. Ridge gourd $\left(\mathrm{T}_{1}\right)$ and bitter gourd $\left(T_{2}\right)$ in tongue grafting $\left(G_{1}\right)$ \& single Cotyledon grafting $\left(G_{3}\right)$, ridge gourd $\left(T_{1}\right)$ and bottle gourd $\left(T_{4}\right)$ in hole insertion grafting $\left(G_{4}\right)$ and real rooted Kalaam, $F 1\left(T_{c}\right)$ didn't show any significant difference in plant height during first season while, in the second season most of the rootstocks didn't 
show any significant difference. Bitter gourd $\left(\mathrm{T}_{2}\right)$ pumpkin $\left(\mathrm{T}_{3}\right)$ bottle gourd $\left(\mathrm{T}_{4}\right)$ in hole Insertion grafting $\left(\mathrm{G}_{4}\right)$ showed maximum time for flowering during both 2017 and 2018 crop seasons respectively. Fruit harvesting time didn't show any significant difference for all grafting technique under both crop seasons. This could be interpreted that cultivation of grafted cucumber produced better plant vegetative growth compared with non-grafted plants in infested soil with nematode and soil salinity. The results are in line with [54] who described that vegetative growth (plant height, branches and leaves) was significantly higher in grafting than that of non-grafting. Hormone synthesis controlled by plant root could lead the plant growth and root to shoot ratios [55]. Zhang [56] stated that the vegetative growth (plant height, leaves, branches, leaf area and stem diameter), photosynthesis rate, yield, wilt resistance and root-knot nematode immunity were higher in scion/rootstock combination plants. The statistical analysis presented in Table 3 indicate the earliness of first female flower on grafted plants.

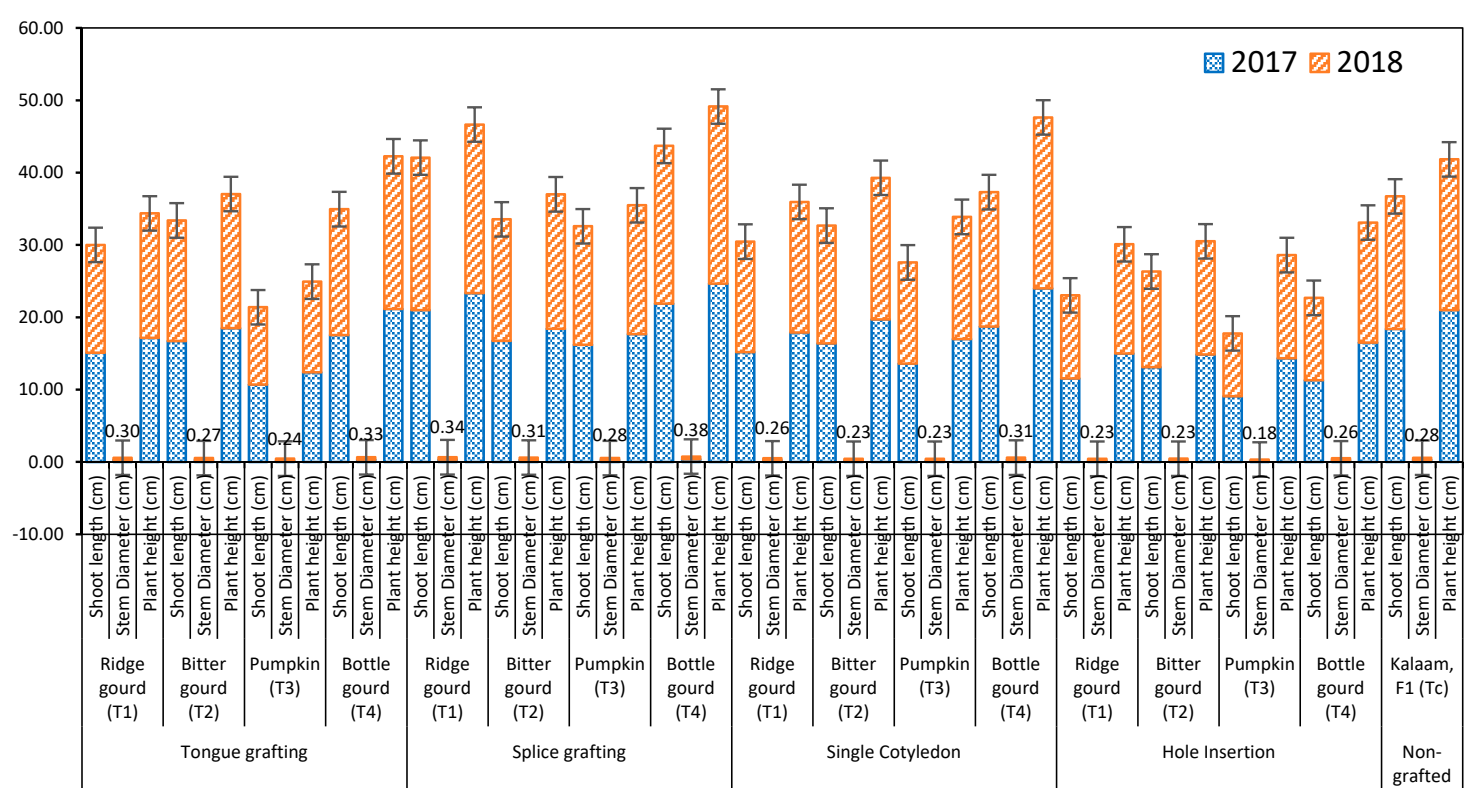

Figure 4. Effect of Scion/rootstocks combinations (grafting) on vegetative growth parameters of Cucumber fruit after 30 days during crop season 2017 and 2018.

The Lagenaria siceraria, Luffa operculata and Momordica charantia started flowering at 33rd day while pumpkin started on 34th day in splice grafting technique as shown in Table 3. The significantly different 62 days were taken by the plants for flowering in hole insertion grafting method. The non-grafted cucumber $\mathrm{cv}$. Kalaam $\mathrm{F}_{1}$ showed flowers after 60 days. Therefore, splice grafted plants showed early and high vigor compared with other grafts and non-grafted plants. The first fruit harvested after 12 days of flowering. The harvesting was carried out at the same time from all kind of grafted plants.

Ozarslandan [57] observed that all genotypes of Lagenaria siceraria (Bottle gourd) were liable to root-knot nematodes. The grafting of scion (Watermelon) onto rootstock (Bottle gourd) gave higher plant growth and fruit yield as compared to non-grafted fruit root-knot nematodes carry soil. It was concluded that bottle gourd rootstock tolerated nematodes with their rapid growth. In this study, splice grafted plants using all scion/rootstock combinations had significantly higher vegetative growth and fruit yield. According to our results, Lee [5] and Ioannou [58] observed that growth of scion/rootstocks were better than that of real rooted plants.

Cansev and Ozgur [42] described that, generally the growth and yield reduced significantly in real rooted (non-grafted) plants as compared with grafting techniques used for scion/rootstock combinations. The results suggested grafting of cucurbitaceous plants avoid yield reduction due to intensive cropping and soil borne disease. Cucumber grafting onto resistant rootstock was recommended technique in soil with high root-knot nematodes infestation and to produce more fruit yield from grafted plants [59]. 
Table 3. Effect of Scion/rootstocks combinations (grafting) on cucumber growth at harvesting stage.

\begin{tabular}{|c|c|c|c|c|c|c|c|c|c|c|c|c|c|}
\hline \multirow{3}{*}{$\begin{array}{l}\text { Grafting } \\
\text { Technique }\end{array}$} & & \multicolumn{6}{|c|}{2017} & \multicolumn{6}{|c|}{2018} \\
\hline & & \multirow{2}{*}{$\begin{array}{c}\text { Plant } \\
\text { Height } \\
(\mathrm{cm})\end{array}$} & \multicolumn{2}{|c|}{ Number/Plant } & \multirow{2}{*}{$\begin{array}{c}\text { Stem } \\
\text { Diameter } \\
(\mathrm{cm})\end{array}$} & \multirow{2}{*}{$\begin{array}{c}\text { Flowering } \\
\text { Time } \\
\text { (Days) }\end{array}$} & \multirow{2}{*}{$\begin{array}{c}\text { First Fruit } \\
\text { Harvesting } \\
\text { Time (Days) }\end{array}$} & \multirow{2}{*}{$\begin{array}{l}\text { Plant } \\
\text { Height } \\
\text { (cm) }\end{array}$} & \multicolumn{2}{|c|}{ Number/Plant } & \multirow{2}{*}{$\begin{array}{c}\text { Stem } \\
\text { Diameter } \\
(\mathrm{cm})\end{array}$} & \multirow{2}{*}{$\begin{array}{c}\text { Flowering } \\
\text { Time } \\
\text { (Days) }\end{array}$} & \multirow{2}{*}{$\begin{array}{c}\text { First Fruit } \\
\text { Harvesting } \\
\text { Time (Days) }\end{array}$} \\
\hline & & & Branches/Plant & Leaves/Plant & & & & & Branches/Plant & Leaves/Plant & & & \\
\hline \multirow{8}{*}{$\begin{array}{c}\text { Tongue } \\
\text { grafting } \\
\left(\mathrm{G}_{1}\right)\end{array}$} & \multirow{2}{*}{ Ridge gourd $\left(\mathrm{T}_{1}\right)$} & $570.0 \pm$ & $10.00 \pm$ & $160.0 \pm$ & $0.95 \pm$ & $34.00 \pm$ & $46.00 \pm$ & $574.0 \pm$ & $11.00 \pm$ & $172.0 \pm$ & $0.93 \pm$ & $34.00 \pm$ & $46.00 \pm$ \\
\hline & & $16.32 \mathrm{a}-\mathrm{d}$ & $0.09 \mathrm{c}$ & $2.97 \mathrm{cde}$ & $0.03 \mathrm{bc}$ & $0.84 \mathrm{ab}$ & $1.07 a^{-}$ & $15.11 \mathrm{abc}$ & $0.25 \mathrm{bc}$ & $4.77 \mathrm{abc}$ & $0.03 \mathrm{bc}$ & $0.58 \mathrm{ab}$ & $1.42 \mathrm{a}$ \\
\hline & \multirow{2}{*}{ Bitter gourd $\left(\mathrm{T}_{2}\right)$} & $566.0 \pm$ & $9.00 \pm$ & $144.0 \pm$ & $0.89 \pm$ & $35.00 \pm$ & $47.00 \pm$ & $561.0 \pm$ & $10.00 \pm$ & $159.0 \pm$ & $0.86 \pm$ & $35.00 \pm$ & $47.00 \pm$ \\
\hline & & $17.87 \mathrm{a}-\mathrm{d}$ & $0.14 \mathrm{~d}$ & $1.98 \mathrm{efg}$ & $0.02 \mathrm{~cd}$ & $0.50 \mathrm{ab}$ & $0.76 a$ & $9.79 \mathrm{abc}$ & $0.19 \mathrm{~cd}$ & $3.08 \mathrm{cde}$ & $0.03 \mathrm{~cd}$ & $0.92 \mathrm{ab}$ & $1.02 \mathrm{a}$ \\
\hline & \multirow{2}{*}{ Pumpkin $\left(\mathrm{T}_{3}\right)$} & $529.0 \pm$ & $9.00 \pm$ & $157.0 \pm$ & $0.70 \pm$ & $34.00 \pm$ & $46.00 \pm$ & $555.0 \pm$ & $9.00 \pm$ & $166.0 \pm$ & $0.72 \pm$ & $34.00 \pm$ & $46.00 \pm$ \\
\hline & & $10.35 \mathrm{~cd}$ & $0.18 \mathrm{~d}$ & $0.99 \mathrm{cde}$ & $0.01 \mathrm{f}-\mathrm{i}$ & $0.37 \mathrm{ab}$ & $0.68 \mathrm{a}$ & $10.64 \mathrm{abc}$ & $0.21 \mathrm{de}$ & $2.57 \mathrm{a}-\mathrm{d}$ & 0.02 efg & $0.33 \mathrm{ab}$ & $0.70 \mathrm{a}$ \\
\hline & \multirow{2}{*}{ Bottle gourd $\left(\mathrm{T}_{4}\right)$} & $600.0 \pm$ & $10.00 \pm$ & $177.0 \pm$ & $1.00 \pm$ & $34.00 \pm$ & $46.00 \pm$ & $595.0 \pm$ & $10.00 \pm$ & $171.0 \pm$ & $1.01 \pm$ & $35.00 \pm$ & $47.00 \pm$ \\
\hline & & 13.87ab & $0.12 \mathrm{c}$ & $3.39 \mathrm{~b}$ & $0.03 \mathrm{~b}$ & $0.96 \mathrm{ab}$ & $0.56 \mathrm{a}$ & 13.81ab & $0.28 \mathrm{~cd}$ & 2.14abc & $0.03 \mathrm{ab}$ & 1.14ab & $0.96 \mathrm{a}$ \\
\hline \multirow{6}{*}{$\begin{array}{c}\text { Splice } \\
\text { grafting } \\
\left(G_{2}\right)\end{array}$} & Ridge gourd $\left(\mathrm{T}_{1}\right)$ & $\begin{array}{c}588.0 \pm \\
12.96 \mathrm{abc}\end{array}$ & $\begin{array}{c}11.00 \pm \\
0.21 \mathrm{~b}\end{array}$ & $\begin{array}{l}163.0 \pm \\
1.06 \mathrm{bcd}\end{array}$ & $\begin{array}{l}1.00 \pm \\
0.02 \mathrm{~b}\end{array}$ & $\begin{array}{c}33.00 \pm \\
0.52 \mathrm{~b}\end{array}$ & $\begin{array}{c}45.00 \pm \\
1.18 \mathrm{a}\end{array}$ & $\begin{array}{l}597.0 \pm \\
18.23 \mathrm{ab}\end{array}$ & $\begin{array}{l}12.00 \pm \\
0.33 \mathrm{ab}\end{array}$ & $\begin{array}{l}177.0 \pm \\
4.76 \mathrm{ab}\end{array}$ & $\begin{array}{l}1.01 \pm \\
0.02 \mathrm{ab}\end{array}$ & $\begin{array}{c}33.00 \pm \\
0.58 \mathrm{~b}\end{array}$ & $\begin{array}{l}45.00 \pm \\
1.26 \mathrm{a}\end{array}$ \\
\hline & \multirow{2}{*}{ Bitter gourd $\left(\mathrm{T}_{2}\right)$} & $567.0 \pm$ & $11.00 \pm$ & $171.0 \pm$ & $0.95 \pm$ & $34.00 \pm$ & $46.00 \pm$ & $575.0 \pm$ & $11.00 \pm$ & $176.0 \pm$ & $0.93 \pm$ & $33.00 \pm$ & $45.00 \pm$ \\
\hline & & $12.14 a-d$ & $0.08 \mathrm{~b}$ & $3.99 \mathrm{bc}$ & $0.01 \mathrm{bc}$ & $0.60 \mathrm{ab}$ & $1.42 \mathrm{a}$ & $16.23 \mathrm{abc}$ & $0.35 b c$ & $2.97 \mathrm{abc}$ & $0.03 \mathrm{bc}$ & $0.54 \mathrm{~b}$ & $0.70 \mathrm{a}$ \\
\hline & \multirow{2}{*}{ Pumpkin $\left(\mathrm{T}_{3}\right)$} & $546.0 \pm$ & $10.00 \pm$ & $159.0 \pm$ & $0.85 \pm$ & $34.00 \pm$ & $46.00 \pm$ & $561.0 \pm$ & $11.00 \pm$ & $169.5 \pm$ & $0.81 \pm$ & $34.00 \pm$ & $46.00 \pm$ \\
\hline & & $3.37 \mathrm{bcd}$ & $0.15 \mathrm{c}$ & 0.75 cde & $0.02 \mathrm{cde}$ & $1.10 \mathrm{ab}$ & $0.69 \mathrm{a}$ & $10.87 \mathrm{abc}$ & $0.12 \mathrm{bc}$ & $2.71 \mathrm{a}-\mathrm{d}$ & $0.02 \mathrm{de}$ & $0.65 \mathrm{ab}$ & $0.61 a^{-}$ \\
\hline & Bottle gourd $\left(\mathrm{T}_{4}\right)$ & $\begin{array}{c}622.0 \pm \\
4.06 \mathrm{a}\end{array}$ & $\begin{array}{c}13.00 \pm \\
0.40 \mathrm{a}\end{array}$ & $\begin{array}{c}194.0 \pm \\
6.32 \mathrm{a}\end{array}$ & $\begin{array}{c}1.13 \pm \\
0.03 a\end{array}$ & $\begin{array}{c}33.00 \pm \\
0.43 \mathrm{~b}\end{array}$ & $\begin{array}{c}45.00 \pm \\
0.64 \mathrm{a}\end{array}$ & $\begin{array}{c}619.0 \pm \\
11.44 \mathrm{a}\end{array}$ & $\begin{array}{c}12.60 \pm \\
0.17 \mathrm{a}\end{array}$ & $\begin{array}{c}182.5 \pm \\
2.70 \mathrm{a}\end{array}$ & $\begin{array}{l}1.10 \pm \\
0.02 a\end{array}$ & $\begin{array}{l}33.00 \pm \\
0.56 \mathrm{~b}\end{array}$ & $\begin{array}{c}45.00 \pm \\
1.25 \mathrm{a}\end{array}$ \\
\hline \multirow{8}{*}{$\begin{array}{c}\text { Single } \\
\text { Cotyledon } \\
\text { grafting } \\
\left(\mathrm{G}_{3}\right)\end{array}$} & \multirow{2}{*}{ Ridge gourd $\left(\mathrm{T}_{1}\right)$} & $540.0 \pm$ & $8.00 \pm$ & $131.0 \pm$ & $0.80 \pm$ & $34.00 \pm$ & $46.00 \pm$ & $534.0 \pm$ & $10.00 \pm$ & $163.0 \pm$ & $0.73 \pm$ & $34.00 \pm$ & $46.00 \pm$ \\
\hline & & $16.62 \mathrm{bcd}$ & $0.21 \mathrm{e}$ & $2.29 \mathrm{ghi}$ & $0.01 \mathrm{def}$ & $1.09 \mathrm{ab}$ & $1.40 \mathrm{a}$ & $7.80 \mathrm{bc}$ & $026 \mathrm{~cd}$ & $3.15 b-\mathrm{e}$ & 0.01efg & $0.82 \mathrm{ab}$ & $1.49 \mathrm{a}$ \\
\hline & \multirow{2}{*}{ Bitter gourd $\left(\mathrm{T}_{2}\right)$} & $535.0 \pm$ & $10.00 \pm$ & $152.0 \pm$ & $0.68 \pm$ & $35.00 \pm$ & $47.00 \pm$ & $543.0 \pm$ & $9.00 \pm$ & $140.0 \pm$ & $0.73 \pm$ & $35.00 \pm$ & $47.00 \pm$ \\
\hline & & $11.66 \mathrm{bcd}$ & $0.10 \mathrm{c}$ & $0.21 \mathrm{def}$ & $0.02 \mathrm{ghi}$ & $0.82 \mathrm{ab}$ & $0.44 a$ & $16.06 \mathrm{bc}$ & $0.16 \mathrm{de}$ & $2.99 \mathrm{f}$ & 0.02 efg & $0.39 \mathrm{ab}$ & $1.03 a$ \\
\hline & Pumnkin (T) & $530.0 \pm$ & $8.00 \pm$ & $138.0 \pm$ & $0.73 \pm$ & $36.00 \pm$ & $48.00 \pm$ & $541.0 \pm$ & $9.00 \pm$ & $153.0 \pm$ & $0.70 \pm$ & $36.00 \pm$ & $48.00 \pm$ \\
\hline & Pumpkin $\left(\mathrm{T}_{3}\right)$ & $8.02 \mathrm{~cd}$ & $0.10 \mathrm{e}$ & $3.09 \mathrm{fgh}$ & $0.02 \mathrm{f}-\mathrm{i}$ & $0.21 \mathrm{ab}$ & $0.60 \mathrm{a}$ & $15.55 \mathrm{bc}$ & $0.11 \mathrm{de}$ & $4.35 \mathrm{def}$ & $0.02 \mathrm{fg}$ & $0.98 \mathrm{ab}$ & $0.50 \mathrm{a}$ \\
\hline & & $570.0 \pm$ & $9.00 \pm$ & $162.0 \pm$ & $0.90 \pm$ & $35.00 \pm$ & $47.00 \pm$ & $575.0 \pm$ & $10.00 \pm$ & $171.6 \pm$ & $0.92 \pm$ & $35.00 \pm$ & $47.00 \pm$ \\
\hline & Bottle gourd $\left(\mathrm{T}_{4}\right)$ & $16.36 a-d$ & $0.17 \mathrm{~d}$ & $4.53 \mathrm{bcd}$ & $0.02 \mathrm{bcd}$ & $0.67 \mathrm{ab}$ & $0.66 \mathrm{a}$ & $14.77 \mathrm{abc}$ & $0.22 \mathrm{~cd}$ & $4.62 \mathrm{abc}$ & $0.02 \mathrm{bc}$ & $0.51 \mathrm{ab}$ & $0.83 a$ \\
\hline & Ridge gourd $\left(\mathrm{T}_{1}\right)$ & $\begin{array}{c}544.0 \pm \\
15.26 \mathrm{bcd}\end{array}$ & $\begin{array}{l}8.00 \pm \\
0.21 \mathrm{e}\end{array}$ & $\begin{array}{l}127.0 \pm \\
3.06 \mathrm{hij}\end{array}$ & $\begin{array}{c}0.78 \pm \\
0.02 \mathrm{efg}\end{array}$ & $\begin{array}{c}36.00 \pm \\
0.63 \mathrm{ab}\end{array}$ & $\begin{array}{c}48.00 \pm \\
0.94 \mathrm{a}\end{array}$ & $\begin{array}{c}571.0 \pm \\
11.11 \mathrm{abc}\end{array}$ & $\begin{array}{c}10.00 \pm \\
0.32 \mathrm{~cd}\end{array}$ & $\begin{array}{l}165.0 \pm \\
3.43 a-d\end{array}$ & $\begin{array}{c}0.77 \pm \\
0.01 \mathrm{~d}-\mathrm{g}\end{array}$ & $\begin{array}{l}35.00 \pm \\
0.60 \mathrm{ab}\end{array}$ & $\begin{array}{c}47.00 \pm \\
0.58 \mathrm{a}\end{array}$ \\
\hline & & $\begin{array}{l}15.2 \mathrm{bocd} \\
509.0 \pm\end{array}$ & $\begin{array}{l}0.210 \\
7.00 \pm\end{array}$ & $\begin{array}{l}3.00 \mathrm{~m}] \\
116.0 \pm\end{array}$ & $\begin{array}{c}0.02 \mathrm{erg} \\
0.67 \pm\end{array}$ & $\begin{array}{l}0.0 \mathrm{aaO} \\
37.00 \pm\end{array}$ & $\begin{array}{c}0.94 \mathrm{a} \\
49.00 \pm\end{array}$ & $521.0 \pm$ & $\begin{array}{l}0.32 \mathrm{ca} \\
8.00 \pm\end{array}$ & $\begin{array}{l}3.438 \mathrm{~d}-\mathrm{a} \\
138.0 \pm\end{array}$ & $\begin{array}{l}0.01 \mathrm{a}-\mathrm{g} \\
0.70 \pm\end{array}$ & $\begin{array}{l}0.600 \mathrm{aO} \\
37.00 \pm\end{array}$ & $\begin{array}{c}0.50 \mathrm{a} \\
49.00 \pm\end{array}$ \\
\hline Insertion & Bitter gourd $\left(\mathrm{T}_{2}\right)$ & $7.95 \mathrm{~d}$ & $0.15 \mathrm{f}$ & $2.09 \mathrm{ij}$ & $0.01 \mathrm{hi}$ & $0.59 a$ & $1.45 a^{-}$ & $9.63 c$ & $0.12 \mathrm{e}^{-}$ & $1.87 \mathrm{f}$ & $0.01 \mathrm{fg}$ & $0.85 a^{-}$ & $1.00 \mathrm{a}^{-}$ \\
\hline grafting & & $412.0 \pm$ & $5.00 \pm$ & $111.0 \pm$ & $0.63 \pm$ & $37.00 \pm$ & $49.00 \pm$ & $401.0 \pm$ & $4.00 \pm$ & $103.0 \pm$ & $0.67 \pm$ & $37.00 \pm$ & $49.00 \pm$ \\
\hline & Pumpkin $\left(\mathrm{T}_{3}\right)$ & $5.21 \mathrm{e}^{-}$ & $0.05 \mathrm{~g}$ & $2.76 j$ & $0.01 \mathrm{i}$ & $0.75 \mathrm{a}$ & $1.45 \mathrm{a}$ & $3.91 \mathrm{~d}$ & $0.06 \mathrm{f}$ & $2.09 \mathrm{~g}$ & $0.02 \mathrm{~g}$ & $0.56 \mathrm{a}$ & $0.32 \mathrm{a}$ \\
\hline & & $565.0 \pm$ & $9.00 \pm$ & $163.0 \pm$ & $0.75 \pm$ & $35.00 \pm$ & $47.00 \pm$ & $561.0 \pm$ & $8.00 \pm$ & $162.0 \pm$ & $0.78 \pm$ & $37.00 \pm$ & $49.00 \pm$ \\
\hline & Bottle gourd $\left(\mathrm{T}_{4}\right)$ & $14.22 \mathrm{a}-\mathrm{d}$ & $0.12 \mathrm{~d}$ & $4.58 \mathrm{bcd}$ & $0.02 \mathrm{e}-\mathrm{h}$ & $0.43 \mathrm{ab}$ & $1.12 \mathrm{a}$ & $6.74 \mathrm{abc}$ & $0.16 \mathrm{e}$ & $2.39 \mathrm{~b}-\mathrm{e}$ & 0.02 def & $0.54 \mathrm{a}$ & $1.23 \mathrm{a}$ \\
\hline $\begin{array}{c}\text { Non-grafted } \\
\left(G_{n}\right)\end{array}$ & Kalaam, $\mathrm{F}_{1}\left(\mathrm{~T}_{\mathrm{c}}\right)$ & $\begin{array}{c}552.0 \pm \\
13.96 \mathrm{bcd}\end{array}$ & $\begin{array}{l}8.00 \pm \\
0.26 \mathrm{e}\end{array}$ & $\begin{array}{l}133.0 \pm \\
0.60 \mathrm{gh}\end{array}$ & $\begin{array}{l}0.72 \pm \\
0.02 f-i\end{array}$ & $\begin{array}{l}34.00 \pm \\
0.65 \mathrm{ab}\end{array}$ & $\begin{array}{c}46.00 \pm \\
0.82 \mathrm{a}\end{array}$ & $\begin{array}{c}571.0 \pm \\
15.82 \mathrm{abc}\end{array}$ & $\begin{array}{l}8.00 \pm \\
0.09 \mathrm{e}\end{array}$ & $\begin{array}{c}147.0 \pm \\
4.36 \mathrm{ef}\end{array}$ & $\begin{array}{l}0.70 \pm \\
0.02 \mathrm{fg}\end{array}$ & $\begin{array}{l}35.00 \pm \\
0.90 \mathrm{ab}\end{array}$ & $\begin{array}{c}47.00 \pm \\
0.36 \mathrm{a}\end{array}$ \\
\hline
\end{tabular}

Means sharing same letters in a column are statistically non-significant $(p>0.05)$. 
The maximum early yield was produced by grafted plants rather than non-grafted plants [60]. Walters and Wehner [61] declared that root-knot nematodes were a major reason of cucumber yield reduction. Zhang [56] observed that grafted cucumber plants onto resistant rootstocks showed earlier flowering and first harvesting time than those of other rootstock and non-grafted plants.

Chen [62] reported that grafted cucumber onto local and resistant rootstocks had higher yields, better quality and a good control on soil pathogenic characteristics. The yield was significantly reduced cucumber fruit yield grown in non-treated soil compared to treated soil [46].

The damage of root-knot nematodes was highest in warm areas which resulted wilting plants under moisture stress [60]. These results agreed with Miguel and Maroto [63], they reported maximum yield in hybrid watermelon grafting and nematodes infested soil than self-rooted planed in fumigated (nematicide) soils. The local and resistant rootstock had enhanced the plant growth, flowering and yield of cucumber fruit [59]. The use of resistant cucurbitaceous rootstocks could increase the cucumber plant growth and fruit yield while the fruit quality was not different [64]. The grafted plants have no significant effect on fruit dry matter but improved nutritional concentration [65].

\subsection{Fruit Growth and Quality}

The effect of four different Scion/rootstocks combinations (grafting) on cucumber fruit, fruit fresh weight, fruit shape index, TSS and fruit dry matter was presented in Table 4 . The splice grafting showed significantly maximum number of fruit per plant (14.60 \pm 0.20 and $15.60 \pm 0.38)$, Fruit weight/cucumber $(122.50 \pm 2.42$ and $121.29 \pm 3.05 \mathrm{~g})$, Fruit shape index (7.88 \pm 0.22 and $7.84 \pm 0.10)$, TSS (5.20 \pm 0.11 and $5.11 \pm 0.15 \%)$ and Fruit dry matter $(4.62 \pm 0.11$ and $4.50 \pm 0.12 \%)$ for Lagenaria siceraria (bottle gourd) during crop season 2017 and 2018 respectively while, the lowest values were associated with pumpkin rootstock. Ridge gourd $\left(\mathrm{T}_{1}\right)$ and bottle gourd $\left(\mathrm{T}_{4}\right)$ in tongue grafting $\left(\mathrm{G}_{1}\right)$, single Cotyledon grafting $\left(G_{3}\right)$ and hole Insertion grafting $\left(G_{4}\right)$ while ridge gourd $\left(T_{1}\right)$ and bitter gourd $\left(T_{2}\right)$ in splice grafting $\left(\mathrm{G}_{2}\right)$ didn't show any significant difference in number of fruits/plants. The real rooted cucumber showed significant different $(10.30 \pm 0.23)$ number of fruits per plant during both seasons. This could be concluded that grafting hybrid cucumber onto local rootstocks gave significant increment in fruit length and diameter (fruit shape index) which results in more fruit yield. These results agreed with Al-Debei [43] who observed that when grafted cucumber cultivar on cucurbitaceous rootstock resulted in more vigorous cucumber plants. Ridge gourd $\left(T_{1}\right)$, bitter gourd $\left(T_{2}\right)$ and pumpkin $\left(T_{3}\right)$ in tongue grafting $\left(G_{1}\right)$, pumpkin $\left(T_{3}\right)$ in splice grafting $\left(G_{2}\right)$, ridge gourd $\left(T_{1}\right)$, bottle gourd $\left(T_{4}\right)$ in single cotyledon grafting $\left(G_{3}\right)$, bitter gourd $\left(T_{2}\right)$ in hole insertion grafting $\left(G_{4}\right)$ and Kalaam, $F 1\left(T_{c}\right)$ in non-grafting $\left(G_{n}\right)$ didn't show any significant difference in fruit weight during first season while in second season bottle gourd $\left(\mathrm{T}_{4}\right)$ in all grafting techniques showed significantly different results. The Kalaam, $F_{1}\left(T_{c}\right)$ also showed significant results for fruit weight. 
Table 4. Effect of Scion/rootstocks combinations (grafting) on cucumber fruit growth and yield. TSS: Total soluble solids

\begin{tabular}{|c|c|c|c|c|c|c|c|c|c|c|c|}
\hline \multirow{2}{*}{$\begin{array}{l}\text { Grafting } \\
\text { Technique }\end{array}$} & \multirow{2}{*}{$\begin{array}{l}\text { Rootstock } \\
\text { Cultivar }\end{array}$} & \multicolumn{5}{|c|}{2017} & \multicolumn{5}{|c|}{2018} \\
\hline & & $\begin{array}{l}\text { Number of } \\
\text { Fruit/Plants }\end{array}$ & $\begin{array}{l}\text { Fruit Weight/ } \\
\text { Cucumber (g) }\end{array}$ & $\begin{array}{l}\text { Fruit Shape } \\
\text { Index }\end{array}$ & TSS (\%) & $\begin{array}{c}\text { Fruit Dry } \\
\text { Matter (\%) }\end{array}$ & $\begin{array}{l}\text { Number of } \\
\text { Fruit/Plants }\end{array}$ & $\begin{array}{l}\text { Fruit Weight/ } \\
\text { Cucumber (g) }\end{array}$ & $\begin{array}{l}\text { Fruit Shape } \\
\text { Index }\end{array}$ & TSS (\%) & $\begin{array}{l}\text { Fruit Dry } \\
\text { Matter (\%) }\end{array}$ \\
\hline \multirow{4}{*}{$\begin{array}{c}\text { Tongue grafting } \\
\qquad\left(\mathrm{G}_{1}\right)\end{array}$} & 1 & $12.60 \pm 0.17$ & (200) & & 2 & $-c$ & $0 \pm 0.33 \mathrm{~b}-\mathrm{d}$ & $.90 \pm 2.45 \mathrm{abc}$ & $7.74 \pm 0.12 \mathrm{ab}$ & 4.7 & 4.32 \\
\hline & & & & & & & & & & & \\
\hline & & & & & & & & & & & \\
\hline & Bottl & 13.0 & 121.40 & $0.12 \mathrm{~b}-\mathrm{e}$ & $5.00 \pm 0.09 \mathrm{ab}$ & $4.56 \pm 0.11 \mathrm{ab}$ & 13.10 & 120.10 & $6.97 \pm 0.10 \mathrm{cde}$ & 5.02 & $0.14 a$ \\
\hline \multirow{4}{*}{$\begin{array}{l}\text { Splice grafting } \\
\qquad\left(\mathrm{G}_{2}\right)\end{array}$} & Bidc & 1 & $116.90 \pm 1.94 a b c$ & $7.75 \pm 0.19 a$ & $c$ & c & $13.90 \pm 0.25 b$ & 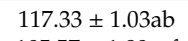 & 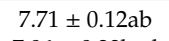 & 4.9 & a \\
\hline & & & & & & & & & & & \\
\hline & & & & & & & & & & & \\
\hline & $\left(\mathrm{T}_{4}\right)$ & 14.60 & $122.50 \pm 2.42 \mathrm{a}$ & $7.88 \pm 0.22 \mathrm{a}$ & $5.20 \pm 0.11$ & $4.62 \pm 0.11 \mathrm{a}$ & 15.60 & $121.29 \pm 3.05 a$ & $7.84 \pm 0.1$ & $5.11 \pm$ & $4.50 \pm 0.12 \mathrm{a}$ \\
\hline \multirow{3}{*}{$\begin{array}{l}\text { Single Cotyledon } \\
\text { grafting }\left(\mathrm{G}_{3}\right)\end{array}$} & & & & & & & & & & & \\
\hline & & & & & & & & & & & 3.6 \\
\hline & Bottle gor & $12.00 \pm 0.18 \mathrm{bc}$ & $113.80 \pm 2.70 \mathrm{a}-\mathrm{d}$ & $6.60 \pm 0.13 \mathrm{de}$ & 4.95 & $0.10 \mathrm{abc}$ & $12.00 \pm 0.14 \mathrm{c}-\mathrm{f}$ & $116.30 \pm 3.43 \mathrm{ab}$ & $6.67 \pm 0.12 \mathrm{def}$ & $4.91 \pm 0.10 \mathrm{ab}$ & $4.29 \pm 0.11 \mathrm{ab}$ \\
\hline \multirow{4}{*}{$\begin{array}{l}\text { Hole Insertion } \\
\text { grafting }\left(\mathrm{G}_{4}\right)\end{array}$} & & & & & & & & 110. & & & \\
\hline & & & & & & & & & & 3.9 & \\
\hline & & & & & & & & & & & \\
\hline & Bottle gourd $\left(\mathrm{T}_{4}\right)$ & $12.00 \pm 0.13 \mathrm{bc}$ & $109.20 \pm 2.99 \mathrm{bcd}$ & $6.31 \pm 0.15 \mathrm{def}$ & $4.78 \pm 0.14 a-d$ & $4.10 \pm 0.04 \mathrm{cde}$ & $12.60 \pm 0.27 \mathrm{~b}-\mathrm{e}$ & $112.90 \pm 1.26 \mathrm{a}-\mathrm{d}$ & $6.30 \pm 0.10$ efg & $4.87 \pm 0.15 \mathrm{ab}$ & $4.02 \pm 0.10 \mathrm{a}-\mathrm{d}$ \\
\hline Non-grafted $\left(G_{n}\right)$ & Kalaam, $\mathrm{F}_{1}\left(\mathrm{~T}_{\mathrm{c}}\right)$ & $30 \pm 0.23 \mathrm{def}$ & $0.80 \pm 1.96 \mathrm{~d}-\mathrm{g}$ & $6.50 \pm 0.15 \mathrm{def}$ & $4.65 \pm 0.11 \mathrm{~b}-\mathrm{f}$ & $4.52 \pm 0.08 \mathrm{abc}$ & $10.00 \pm 0.15 \mathrm{~g}$ & $103.60 \pm 0.84$ def & $6.45 \pm 0.07 \mathrm{~d}-\mathrm{g}$ & $4.62 \pm 0.14 \mathrm{abc}$ & $4.40 \pm 0.12 \mathrm{a}$ \\
\hline
\end{tabular}

Means sharing same letters in a column are statistically non-significant $(p>0.05)$. 
The results of fruit dry matter obtained from ridge gourd $\left(\mathrm{T}_{1}\right)$, bitter gourd $\left(\mathrm{T}_{2}\right)$ and pumpkin $\left(T_{3}\right)$ in tongue grafting $\left(G_{1}\right)$ and splice grafting $\left(G_{2}\right)$, ridge gourd $\left(T_{1}\right)$ and bottle gourd $\left(T_{4}\right)$ in single cotyledon grafting $\left(\mathrm{G}_{3}\right)$, bitter gourd $\left(\mathrm{T}_{2}\right)$ in hole insertion grafting $\left(\mathrm{G}_{4}\right)$ and real rooted Kalaam, $\mathrm{F} 1\left(\mathrm{~T}_{\mathrm{c}}\right)$ during first crop season 2017 were not statistically different. During second season, all rootstocks in splice grafting and real rooted Kalaam, $\mathrm{F}_{1}$ didn't show any significant difference. These results are in line with Yetistir and Sari [66] who reported that grafted cucumber fruit with higher fruit fresh weight and dry matter had more nutritional concentration compared with low fresh weight cucumber fruit. Grafting of cucumber scion onto bottle gourd rootstock can enhance the reduction of cucumber fruit dry matter [67]. Ridge gourd $\left(T_{1}\right)$ in tongue grafting $\left(G_{1}\right)$, bitter gourd $\left(T_{2}\right)$ in splice grafting $\left(G_{2}\right)$ didn't show any significant difference. Bottle gourd $\left(T_{4}\right)$ in tongue grafting $\left(G_{1}\right)$ and single cotyledon grafting $\left(G_{3}\right)$ similarly pumpkin $\left(T_{3}\right)$ in tongue grafting $\left(G_{1}\right)$ and ridge gourd $\left(T_{1}\right)$ in hole insertion grafting $\left(\mathrm{G}_{4}\right)$ didn't show any significant difference for TSS in fruit juice during first crop season while in the second season, ridge gourd $\left(T_{1}\right)$ in tongue grafting $\left(G_{1}\right)$ and splice grafting $\left(G_{2}\right)$ and bottle gourd $\left(T_{4}\right)$ in single cotyledon grafting $\left(G_{3}\right)$ and hole insertion grafting $\left(G_{4}\right)$ didn't show any significant TSS contents but real rooted plants showed statistically significant TSS [54]. During first crop season bottle gourd $\left(\mathrm{T}_{4}\right)$ and ridge gourd $\left(\mathrm{T}_{1}\right)$ in splice grafting $\left(\mathrm{G}_{2}\right)$ didn't show any significant difference. The real rooted plants showed statistically different results in season 2018 but not in 2017.

Plant hormones regulate plant vegetative growth and reproductive development and are responsible for built root-shoot communication [68]. Plant with healthy rootstock produce more cytokinins into rising xylem sap which enhanced fruit yield [68]. The grafting changed hormones production and their impact on grafted plants. Flowering are controlled by plant hormones. It could be concluded that grafting increased the fruit yield since grafted plants have strong root system which improved disease immunity and photosynthesis. The plant growth of grafted cucumber and the resemblance of protective isozymes between grafted and non-grafted plants had a positive correlation [69].

The Table 5 indicated the effect of scion (cucumber $\mathrm{cv}$. Kalaam $\mathrm{F}_{1}$ ) grafted onto four local rootstocks (ridge gourd, bitter gourd, pumpkin and bottle gourd) with different grafting techniques on quality of cucumber fruit. The fruit quality was evaluated at 3,6 and 9 days after pollination. It is clear from the Table that the contents of ascorbic acid in fruit decreased significantly with the fruit growth. The ascorbic acid, soluble protein and free amino acid decreased with periodically while soluble sugar content increased. The contents of ascorbic acid in cucumber cv. Kalaam $\mathrm{F}_{1}$ fruit were higher initial days and then decrease gradually. Bottle gourd gave statistically significant results while the pumpkin showed lowest values. The ridge gourd, bitter gourd and real rooted plants didn't show any significant difference during both seasons. The cucumber $\mathrm{cv}$. Kalaam $\mathrm{F}_{1}$ fruit grafted onto bottle gourd had statistically significant soluble protein content during first and second seasons while pumpkin rootstock showed least values. The statistical difference was not found in other rootstocks. Free amino acid and soluble sugar didn't show any significant difference in all rootstocks during both seasons. 
Table 5. Effect of Scion/rootstocks combinations (grafting) on Cucumber fruit quality.

\begin{tabular}{|c|c|c|c|c|c|c|c|c|c|c|c|}
\hline \multirow[b]{2}{*}{ Fruit Quality } & \multirow[b]{2}{*}{ DAP (Days) } & \multicolumn{5}{|c|}{2017} & \multicolumn{5}{|c|}{2018} \\
\hline & & $\begin{array}{c}\text { Ridge Gourd } \\
\left(\mathrm{T}_{1}\right)\end{array}$ & $\begin{array}{l}\text { Bitter Gourd } \\
\left(T_{2}\right)\end{array}$ & Pumpkin $\left(\mathrm{T}_{3}\right)$ & $\begin{array}{l}\text { Bottle Gourd } \\
\left(T_{4}\right)\end{array}$ & $\begin{array}{c}\text { Kalaam, } F 1 \\
\left(T_{c}\right)\end{array}$ & $\begin{array}{l}\text { Ridge Gourd } \\
\left(\mathrm{T}_{1}\right)\end{array}$ & $\begin{array}{c}\text { Bitter Gourd } \\
\left(T_{2}\right)\end{array}$ & Pumpkin $\left(T_{3}\right)$ & $\begin{array}{l}\text { Bottle Gourd } \\
\left(\mathrm{T}_{4}\right)\end{array}$ & $\begin{array}{c}\text { Kalaam, } F 1 \\
\left(T_{c}\right)\end{array}$ \\
\hline \multirow{2}{*}{$\begin{array}{l}\text { Ascorbic Acid } \\
\text { (mg/100 g FW) }\end{array}$} & 3 & $52.70 \pm 1.31 \mathrm{ab}$ & $48.10 \pm 0.96 b$ & $40.80 \pm 1.27 \mathrm{c}$ & $56.10 \pm 0.90 a$ & $49.40 \pm 0.31 \mathrm{~b}$ & $52.90 \pm 1.21 \mathrm{ab}$ & $48.50 \pm 0.63 b$ & $41.50 \pm 0.96 c$ & $55.70 \pm 0.99 a$ & $49.10 \pm 1.08 \mathrm{~b}$ \\
\hline & 6 & $42.40 \pm 0.78 \mathrm{ab}$ & $39.10 \pm 0.97 \mathrm{~b}$ & $31.30 \pm 0.65 c$ & $44.00 \pm 0.67 \mathrm{a}$ & $38.80 \pm 1.03 \mathrm{~b}$ & $42.00 \pm 0.61 \mathrm{ab}$ & $38.40 \pm 0.65 b c$ & $32.60 \pm 0.92 \mathrm{~d}$ & $43.50 \pm 0.35 a$ & $38.30 \pm 1.12 c$ \\
\hline \multirow{3}{*}{$\begin{array}{l}\text { Soluble Protein } \\
\text { (mg/g FW) }\end{array}$} & 3 & $15.30 \pm 0.21 b$ & $12.90 \pm 0.37 c$ & $11.10 \pm 0.29 \mathrm{~d}$ & $17.30 \pm 0.47 a$ & $14.10 \pm 0.33 b c$ & $15.60 \pm 0.40 \mathrm{~b}$ & $13.20 \pm 0.39 c$ & $11.50 \pm 0.24 \mathrm{~d}$ & $17.20 \pm 0.26 a$ & $13.50 \pm 0.21 \mathrm{c}$ \\
\hline & 6 & $12.60 \pm 0.14 a$ & $9.50 \pm 0.23 b$ & $7.80 \pm 0.13 c$ & $5.00 \pm 0.06 \mathrm{~d}$ & $9.60 \pm 0.17 \mathrm{~b}$ & $12.50 \pm 0.13 a$ & $9.40 \pm 0.26 \mathrm{~b}$ & $8.10 \pm 0.10 c$ & $4.90 \pm 0.03 \mathrm{~d}$ & $9.20 \pm 0.16 \mathrm{~b}$ \\
\hline & 9 & $10.10 \pm 0.17 \mathrm{~b}$ & $7.50 \pm 0.12 \mathrm{~d}$ & $6.70 \pm 0.19 \mathrm{e}$ & $12.40 \pm 0.14 \mathrm{a}$ & $8.50 \pm 0.07 c$ & $10.40 \pm 0.14 \mathrm{~b}$ & $7.70 \pm 0.20 \mathrm{c}$ & $6.80 \pm 0.22 \mathrm{~d}$ & $12.30 \pm 0.11 \mathrm{a}$ & $8.00 \pm 0.21 c$ \\
\hline \multirow{2}{*}{$\begin{array}{l}\text { Free amino acid } \\
(\mathrm{mg} / 100 \mathrm{~g} \text { FW })\end{array}$} & 3 & $3.80 \pm 0.06 a$ & $3.40 \pm 0.09 \mathrm{bc}$ & $3.10 \pm 0.04 c$ & $3.70 \pm 0.09 \mathrm{ab}$ & $3.50 \pm 0.06 \mathrm{ab}$ & $3.70 \pm 0.12 \mathrm{a}$ & $3.30 \pm 0.02 b c$ & $3.10 \pm 0.08 c$ & $3.60 \pm 0.05 \mathrm{ab}$ & $3.10 \pm 0.05 c$ \\
\hline & 6 & $2.80 \pm 0.06 \mathrm{~b}$ & $2.70 \pm 0.02 \mathrm{~b}$ & $2.70 \pm 0.02 \mathrm{~b}$ & $4.20 \pm 0.09 \mathrm{a}$ & $2.20 \pm 0.02 c$ & $2.90 \pm 0.03 \mathrm{~b}$ & $2.80 \pm 0.09 \mathrm{~b}$ & $2.60 \pm 0.08 \mathrm{~b}$ & $4.10 \pm 0.09 \mathrm{a}$ & $2.60 \pm 0.08 \mathrm{~b}$ \\
\hline \multirow{3}{*}{$\begin{array}{l}\text { Soluble Sugar } \\
\text { (mg/g FW) }\end{array}$} & 3 & $5.00 \pm 0.14 a$ & $4.50 \pm 0.12 \mathrm{ab}$ & $4.40 \pm 0.14 \mathrm{~b}$ & $5.00 \pm 0.12 a$ & $4.40 \pm 0.07 \mathrm{~b}$ & $4.90 \pm 0.16 a$ & $4.60 \pm 0.08 \mathrm{a}$ & $4.50 \pm 0.07 \mathrm{a}$ & $4.90 \pm 0.16 a$ & $4.50 \pm 0.08 \mathrm{a}$ \\
\hline & 6 & $5.90 \pm 0.14 a$ & $5.60 \pm 0.09 \mathrm{ab}$ & $5.20 \pm 0.06 b$ & $5.80 \pm 0.18 \mathrm{a}$ & $5.20 \pm 0.11 \mathrm{~b}$ & $5.80 \pm 0.06 a$ & $5.50 \pm 0.12 a$ & $5.10 \pm 0.04 \mathrm{~b}$ & $5.60 \pm 0.04 a$ & $5.00 \pm 0.04 b$ \\
\hline & 9 & $6.80 \pm 0.11 \mathrm{a}$ & $6.20 \pm 0.12 \mathrm{~b}$ & $6.10 \pm 0.07 \mathrm{~b}$ & $7.00 \pm 0.06 \mathrm{a}$ & $6.30 \pm 0.06 \mathrm{~b}$ & $6.60 \pm 0.15 a b$ & $6.30 \pm 0.14 \mathrm{bc}$ & $6.00 \pm 0.06 c$ & $6.90 \pm 0.09 \mathrm{a}$ & $6.10 \pm 0.09 \mathrm{bc}$ \\
\hline
\end{tabular}

Means sharing same letters in a row are statistically non-significant $(p>0.05)$, DAP: days after pollination. 
The Table 6 indicated the mineral composition of scion/rootstock combinations (grafts) and non-grafted cucumber cv. Kalaam $\mathrm{F}_{1}$. Fruit N, P, K, Ca and Mg of hybrid cucumber grafted onto bottle gourd were significantly more among other rootstock and self-rooted cucumber fruits. The lowest values were associated with pumpkin rootstock. Scion/rootstock enhanced mineral circulation in plants. The contents of Potassium $(\mathrm{K})$ and magnesium $(\mathrm{Mg})$ in grafted fruits were statistically significant as compared to non-grafted fruits which was based on vigorous rootstock development responsible for absorbing water and nutrients effectively than other real roots [5]. The bottle gourd rootstock showed significantly maximum N, P, K, Ca and Mg contents during both crop seasons. Bitter gourd $\left(T_{2}\right)$ and Kalaam, $F_{1}\left(T_{c}\right)$ didn't show any significantly difference during first season while, during second season all rootstocks had statistically different nitrogen contents. Ridge and bottle gourd didn't show any significant difference of phosphorus content during 2017 while results were statistically different for all rootstock in second season. Statistically no different results of $\mathrm{K}$, $\mathrm{Ca}$ and $\mathrm{Mg}$ were found between both seasons. Although the scion/rootstock combinations determine fruit quality and nutritional contents, there was a significant influence of grafting found on fruit quality as compared to the original rooted plants. Therefore, the cucumber cv. Kalaam F1 grafted on four local root stocks (ridge gourd, bitter gourd, pumpkin and bottle gourd) have an improved mineral composition that can be used for commercial production.

Salehi-Muhammadi [70] described how the impact of rootstock on mineral composition depended upon the development of root genotypes which improved water and mineral transfer. The low performance of other rootstocks and non-grafted plants compared to the bottle gourd rootstock were justified by unsuitable grafting, which can cause improper scion growth or depression and mineral transfer from the union of grafting [42,71,72]. Several studies have been conducted to explain that effect in scion due to grafting techniques and the transport of genes from the local root system and hybrid scion through vascular bundles [73-75]. The rate of mineral transfer was higher in bottle gourd than other grafted and non-grafted plants, and tolerated a high crop load [76].

The fresh weight, length and diameter of cucumber fruit grafted on different cucurbitaceous rootstocks were presented in Figure 5. The observation carried out at the time of harvesting didn't show any significant difference in fruit weight, fruit length and fruit diameter during both crop seasons 2017 and 2018. The splice grafting of cucurbitaceous rootstock with hybrid cucumber fruit showed significantly maximum physical properties of cucumber fruit. The splice grafting showed significant fresh fruit weight $(\mathrm{g})$ in bottle gourd $(280.50 \pm 3.39$ and $277.00 \pm 5.32)$, ridge gourd $(252.00 \pm 4.29$ and $265.00 \pm 7.31)$, bitter gourd (243.00 \pm 3.34 and $252.00 \pm 5.33)$ and pumpkin (227.00 \pm 5.43 and $234.00 \pm 1.68$ ). All rootstocks showed significantly different fruit fresh weight during 2017 and 2018 . The fruit length of cucumber showed statistically different results. Ridge gourd in tongue grafting and single cotyledon grafting while bitter gourd and pumpkin and ridge gourd and bottle gourd in splice grafting didn't show significant difference during first season but in second season the complete results obtained were statistically different. The fruit diameter was not statistically different during the first season but in the second season the results of fruit diameter were statistically different. 
Table 6. Effect of Scion/rootstocks combinations on mineral contents in cucumber fruit.

\begin{tabular}{|c|c|c|c|c|c|c|c|c|c|c|}
\hline \multirow{2}{*}{$\begin{array}{c}\text { Mineral } \\
\text { Composition }\end{array}$} & \multicolumn{5}{|c|}{2017} & \multicolumn{5}{|c|}{2018} \\
\hline & $\mathbf{N}$ & $\mathbf{P}$ & $\mathbf{K}$ & $\mathrm{Ca}$ & $\mathrm{Mg}$ & $\mathbf{N}$ & $\mathbf{P}$ & K & $\mathrm{Ca}$ & $\mathrm{Mg}$ \\
\hline Ridge gourd $\left(\mathrm{T}_{1}\right)$ & $2.34 \pm 0.03 b$ & $0.88 \pm 0.01 a$ & $4.90 \pm 0.11 a$ & $0.37 \pm 0.00 \mathrm{a}$ & $0.40 \pm 0.00 a$ & $2.30 \pm 0.05 b$ & $0.80 \pm 0.02 \mathrm{ab}$ & $4.85 \pm 0.11 \mathrm{a}$ & $0.33 \pm 0.01 a$ & $0.38 \pm 0.01 a$ \\
\hline Bitter gourd $\left(\mathrm{T}_{2}\right)$ & $2.17 \pm 0.04 b c$ & $0.80 \pm 0.02 b$ & $4.40 \pm 0.11 b$ & $0.30 \pm 0.01 b$ & $0.34 \pm 0.00 b$ & $2.10 \pm 0.02 \mathrm{~cd}$ & $0.74 \pm 0.02 b c$ & $4.34 \pm 0.05 b$ & $0.27 \pm 0.00 b$ & $0.31 \pm 0.01 b$ \\
\hline Pumpkin $\left(\mathrm{T}_{3}\right)$ & $2.10 \pm 0.05 c$ & $0.68 \pm 0.01 c$ & $4.27 \pm 0.07 \mathrm{~b}$ & $0.27 \pm 0.01 b$ & $0.27 \pm 0.00 c$ & $2.00 \pm 0.04 \mathrm{~d}$ & $0.70 \pm 0.02 c$ & $4.21 \pm 0.11 b$ & $0.22 \pm 0.00 c$ & $0.25 \pm 0.00 c$ \\
\hline Bottle gourd $\left(\mathrm{T}_{4}\right)$ & $3.00 \pm 0.05 a$ & $0.90 \pm 0.01 a$ & $4.99 \pm 0.09 a$ & $0.37 \pm 0.01 a$ & $0.42 \pm 0.01 a$ & $2.90 \pm 0.04 a$ & $0.87 \pm 0.01 \mathrm{a}$ & $4.93 \pm 0.13 a$ & $0.35 \pm 0.00 \mathrm{a}$ & $0.40 \pm 0.00 \mathrm{a}$ \\
\hline Kalaam, $\mathrm{F}_{1}(\mathrm{Tc})$ & $2.27 \pm 0.04 b c$ & $0.73 \pm 0.01 c$ & $4.27 \pm 0.10 b$ & $0.30 \pm 0.00 b$ & $0.33 \pm 0.01 b$ & $2.20 \pm 0.02 b c$ & $0.71 \pm 0.02 c$ & $4.30 \pm 0.08 b$ & $0.26 \pm 0.01 b$ & $0.31 \pm 0.01 b$ \\
\hline
\end{tabular}

Means sharing same letters in a row are statistically non-significant $(p>0.05)$ 


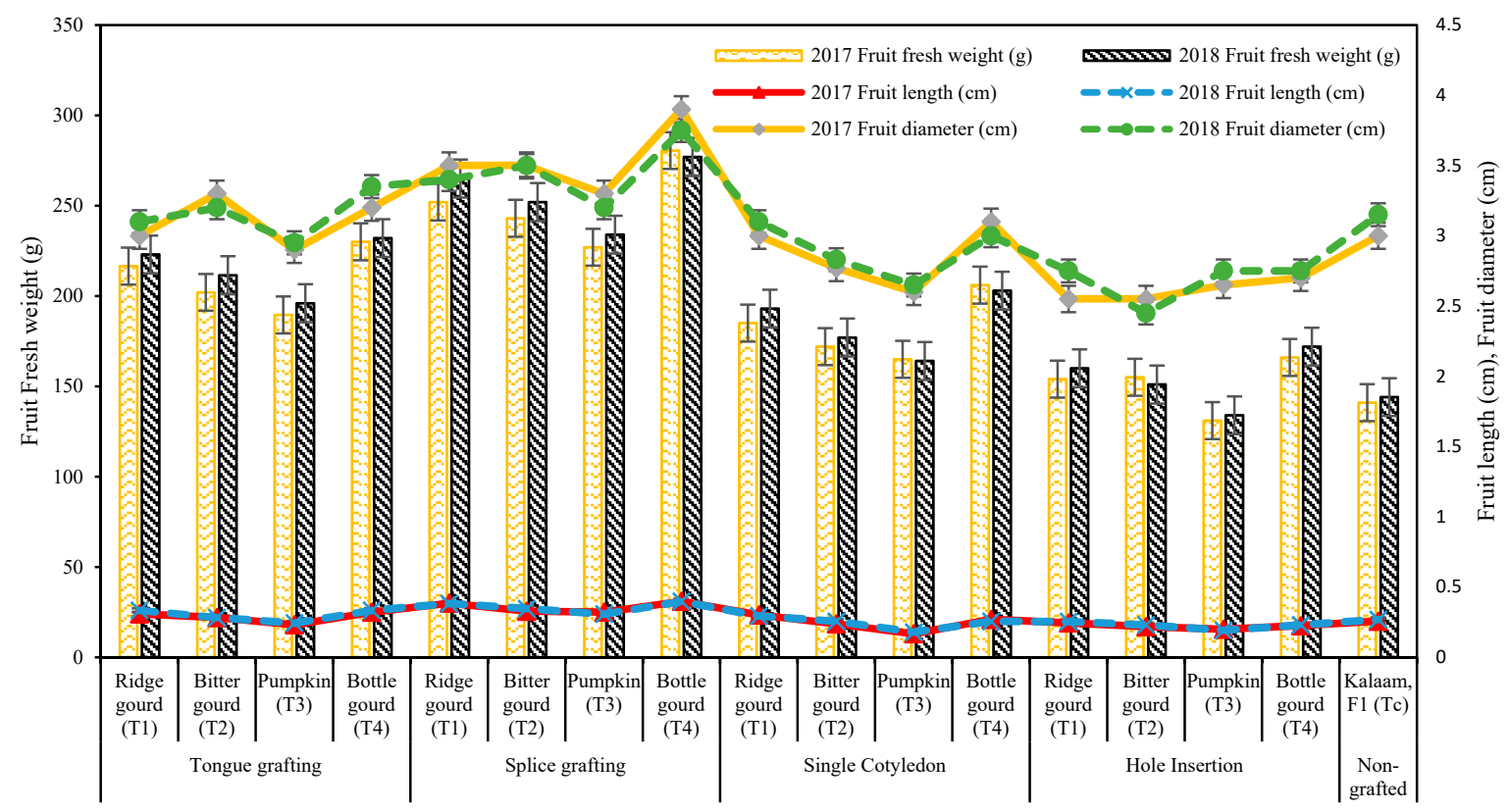

Figure 5. Effect of scion/rootstocks combinations (grafting) on physical properties of Cucumber fruit.

The effect of grafting cucumber $\mathrm{cv}$. Kalaam $\mathrm{F}_{1}$ onto local rootstocks on daily mean fresh weight of fruit, average length and average diameter of cucumber fruit during crop seasons 2017 and 2018 is presented in Figures 6-8. Figure 6 illustrates that after 4 days of pollination, the mean weight of fruit was increased significantly as shown in the Figure 6A-D. The fresh fruit weights $(\mathrm{g})$ of all scion/rootstock combination in splice grafting were found significantly maximum than other grafted and real rooted cucumber plants during both 2017 and 2018 crop seasons. At day 9 after pollination, the fresh weight of splice grafting was $(270 \mathrm{~g})$ statistically significant for bottle gourd while the ridge gourd and bitter gourd ( $261 \mathrm{~g}$ and $24 \mathrm{7g}$ ) didn't show significant differences in fruit fresh weight. The pumpkin rootstock and real rooted cucumber $\mathrm{cv}$. Kalaam $\mathrm{F}_{1}$ had non-significant fruit fresh weight 161 and 138.25 grams. During both 2017 and 2018 crop seasons length of cucumber fruit (cm) improved significantly after pollination while from 3-8 days showed maximum fruit length in all scion/rootstock combinations as shown in Figure 7A-D. The fruit lengths in splice grafting were significantly longer as compared to that in other grafting and non-grafting methods. After 9 days of pollination for two years, bottle gourd had significantly higher length of cucumber while ridge gourd and bitter gourd didn't show significant differences of fruit length. The pumpkin and real rooted plants had non-significant mean fruit length. The diameter of cucumber fruit $(\mathrm{cm})$ didn't increased significantly from day 1-3 and enhanced significantly from day 3-9 after pollination as shown in Figure 8A-D. Grafted plants had a significantly larger diameter of cucumber fruit while real rooted plants showed non-significant fruit diameter. After day 9 the diameter of cucumber plants in splice grafting were significantly higher $3.5,3.3,3.4$ and $3.7 \mathrm{~cm}$. The diameter of non-grafted cucumber fruit $(3.1 \mathrm{~cm})$ didn't show significant difference while the non-significant diameters of cucumber fruits were found 2.7, 2.6, 2.7 and $2.7 \mathrm{~cm}$ in hole insertion grafting of ridge gourd, bitter gourd, pumpkin and bottle gourd respectively. It could be concluded that the grafted plants had significantly higher weight, length and diameter of fresh fruit than those of fresh fruit in non-grafting. The results agreed with studies on citrus [77], grapes [78], lemon [79], mango [80] and melon [81] grafted on appropriate rootstocks. 

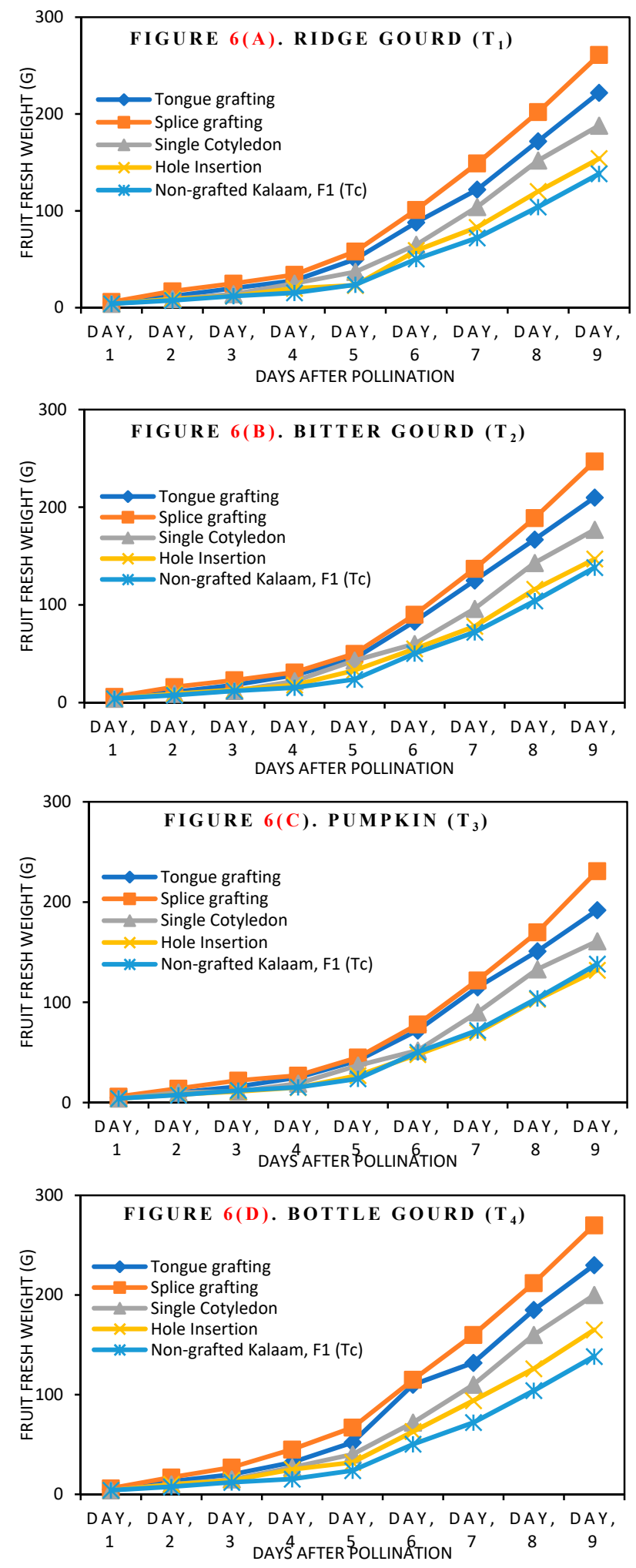

Figure 6. (A-D). Effect of scion/rootstocks combinations (grafting) on fresh weight of Cucumber fruit. 

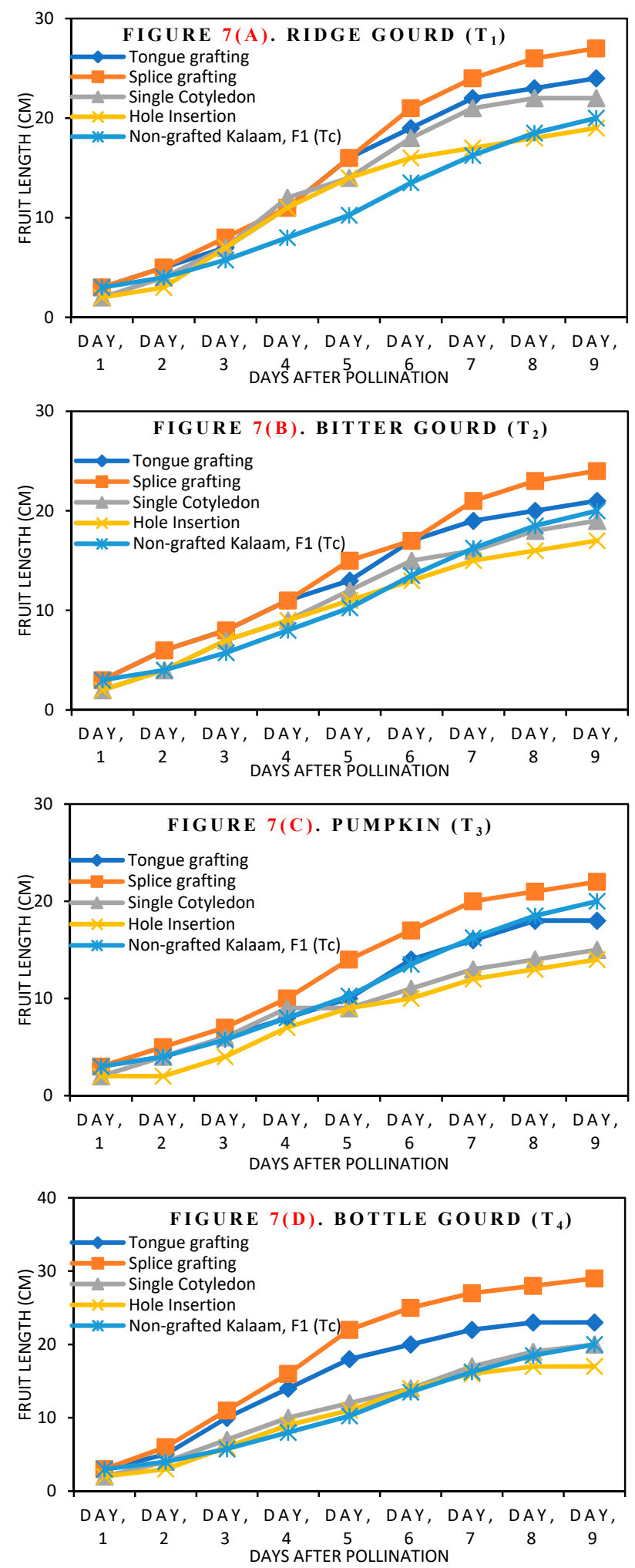

Figure 7. (A-D). Effect of grafting on Cucumber fruit development (fruit length) after pollination. 

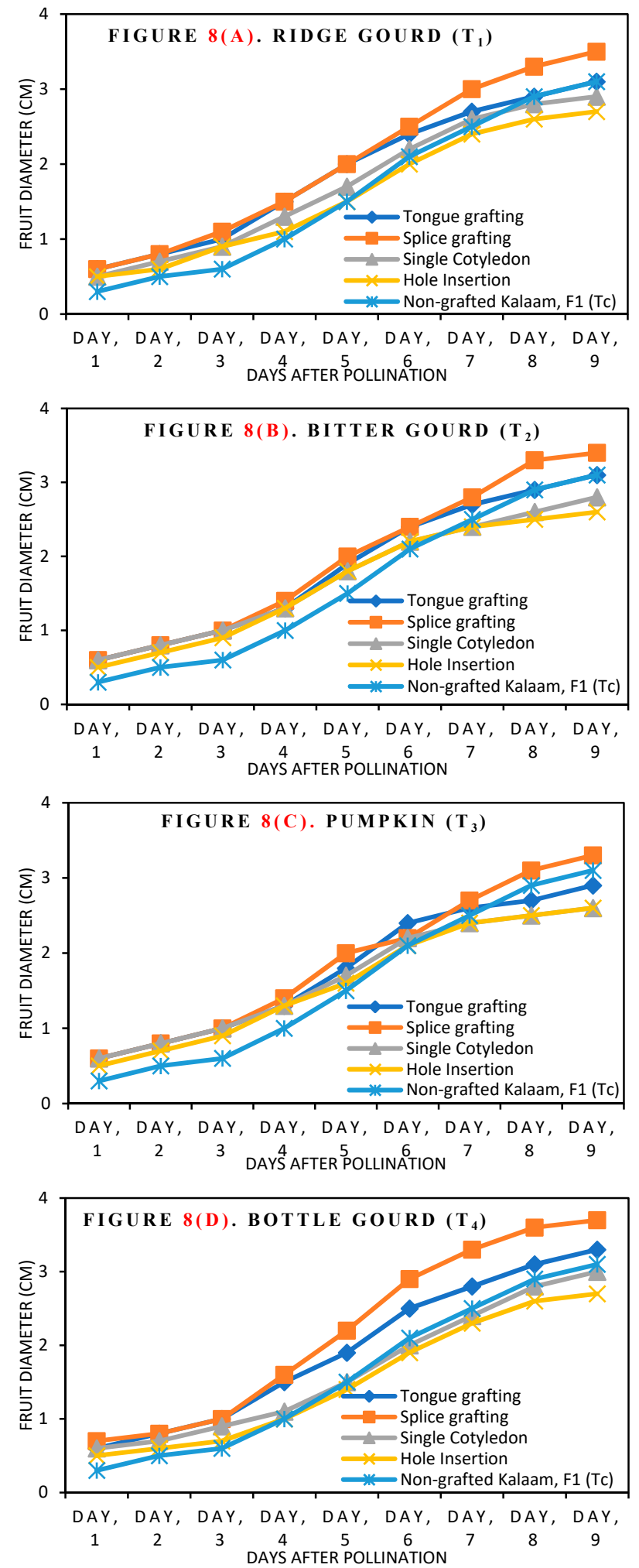

Figure 8. (A-D). Effect of grafting on Cucumber fruit development (fruit diameter) after pollination.

\section{Conclusions}

The pathological and soil-borne diseases particularly root-knot nematode represent major constraints for good seed germination, plant survival and growth, fruit development and fruit quality in cucumber production. There is no cucumber hybrid variety tolerant to nematode while fumigation of nematicides are expensive and can damage a sustainable agriculture system. Therefore, 
grafting is a real agricultural practice to control disease, and to improve cucumber production and quality in a suitable growing environment. The optimum plant vegetative growth, yield and fruit quality are based on both shoot and root genotypes. This study aimed to select and evaluate the resistant and tolerant scion/rootstock combination. The scion of hybrid cucumber cv. Kalaam $\mathrm{F}_{1}$ and four local cucurbitaceous rootstocks were combined through tongue grafting (TAG), splice grafting, single cotyledon grafting and hole insertion grafting during 2017 and 2018. All scion/rootstocks combinations showed significantly maximum results in splice grafting than other grafting and non-grafted (self-rooted) plants. The hybrid cucumber $\mathrm{cv}$. Kalaam $\mathrm{F}_{1}$ grafted on bottle gourd rootstock gave significantly highest survival rate, plant vegetative growth, yield, fruit quality and resistance against soil-borne disease in splice grafting method followed by tongue approach, single cotyledon and hole insertion grafting. The non-significant values were associated with hole insertion grafting method in all scion/rootstock combinations. Grafting had no effect on cucumber fruit matter and fruit quality but fruit mineral composition (N, P, K, Ca and $\mathrm{Mg}$ ) was improved significantly. Thus, grafting hybrid cucumber onto local rootstocks improved the growth, yield and quality of fruit, as well as the development of immunity to disease. The studies suggested that grafting of hybrid cucumber cv. Kalaam $\mathrm{F}_{1}$ on local rootstocks grow well in infested soil to control soil-borne disease and to enhance cucumber production.

Author Contributions: Conceptualization, Design and Development, R.S.N.; Data collection, R.S.N., W.A. and M.I.; Formal Analysis, R.S.N., M.U.K. and M.A.; Investigation and Methodology, R.S.N., S.-U.R. and Z.W.; Supervision, M.U. and Y.S.; Visualization, R.S.N. and M.U.; Writing—original draft, R.S.N.; Writing review, Y.S., M.Y. and M.U.K.; Write-up editing, R.S.N.

Funding: This research received no external funding.

Acknowledgments: The authors would like to acknowledge to all the services and technical support of Horticultural research station, University of Agriculture Faisalabad, Faculty of Agricultural Engineering and Technology PMAS-Arid Agriculture University Rawalpindi and Department of Agriculture, Biological, Environment and Energy Engineering, College of Engineering, Northeast Agricultural University, Harbin provided during research work setting, instrumentation, data collection and write-up compilation.

Conflicts of Interest: The authors declared no conflict of interest.

\section{References}

1. Pina, A.Y.; Errea, P. A review of new advances in mechanism of graft compatibility-incompatibility. Sci. Hortic. 2005, 106, 1-11. [CrossRef]

2. Mudge, K.; Janick, J.; Scoffield, S.; Goldschmidt, E.E. A history of grafting. Hortic. Rev. 2009, 35, 437-494.

3. Hartmann, H.T.; Kester, D.E.; Davies, F.T.; Geneve, R.L. Principles of grafting and budding. In Plant Propagation: Principles and Practices, 8th ed.; Pearson: London, UK, 2010; Chapter 11; pp. 415-463. ISBN 978-0-13-501449-3.

4. Lee, J.M.; Kubota, C.; Tsao, S.J.; Bie, Z.; Hoyos, E.P.; MorraL, O.M. Current status of vegetable grafting: diffusion, grafting techniques, automation. Sci. Hortic. 2010, 127, 93-105. [CrossRef]

5. Lee, J.M. Cultivation of grafted vegetables I. Current status, grafting methods, and benefits. Hortic. Sci. 1994, $29,235-239$.

6. Hartman, G.; Pawlowski, M.; Herman, T.; Eastburn, D. Organically Grown Soybean Production in the USA: Constraints and Management of Pathogens and Insect Pests. Agronomy 2016, 6, 16. [CrossRef]

7. Diacono, M.; Persiani, A.; Fiore, A.; Montemurro, F.; Canali, S. Agro-Ecology for Potential Adaptation of Horticultural Systems to Climate Change: Agronomic and Energetic Performance Evaluation. Agronomy 2017, 7, 35. [CrossRef]

8. St. Amand, P.C.; Wehner, T.C. Crop loss to 14 diseases in cucumber in North Carolina for 1983 to 1988. Cuc. Genet. Coop. Rep. 1999, 14, 15-17.

9. Pradeep, K.; Youssef, R.; Mariateresa, C.; Giuseppe, C. Vegetable Grafting as a Tool to Improve Drought Resistance and Water Use Efficiency. Front. Plant Sci. 2017, 8, 1130. [CrossRef]

10. Huang, Y.; Bie, Z.; He, S.; Hua, B.; Zhen, A.; Liu, Z. Improving cucumber tolerance to major nutrients induced salinity by grafting onto Cucurbita ficifolia. Environ. Exp Bot. 2010, 69, 32-38. [CrossRef] 
11. Schwarz, D.; Rouphael, Y.; Colla, G.; Venema, J.H. Grafting as a tool to improve tolerance of vegetables to abiotic stresses: Thermal stress, water stress and organic pollutants. Sci. Hortic. 2010, 127, 162-171. [CrossRef]

12. Colla, G.; Rouphael, Y.; Rea, E.; Cardarelli, M. Grafting cucumber plants enhance tolerance to sodium chloride and sulfate salinization. Sci. Hortic. 2012, 135, 177-185. [CrossRef]

13. Moore, R. A model for graft compatibility-incompatibility in higher plants. Am. J. Bot. 1984, 71, 751-758. [CrossRef]

14. De Miguel, A.; Cebolla, V. Terralia 53, Unión del Injerto; Terralia: Madrid, Spain, October 2005; pp. 50-60. Available online: https://www.terralia.com/terralias/view_report?magazine_report_id=365 (accessed on 5 January 2018).

15. Kumar, R.M.S.; Gao, L.X.; Yuan, H.W.; Xu, D.B.; Liang, Z.; Tao, S.C.; Guo, W.B.; Yan, D.L.; Zheng, B.S.; Edqvist, J. Auxin enhances grafting success in Carya cathayensis (Chinese hickory). Planta 2018, 247, 761-772. [CrossRef]

16. Melnyk, C.W. Plant grafting: Insights into tissue regeneration. Regeneration 2017, 4, 3-14. [CrossRef]

17. De Velasco Alvarado, M.J. Anatomía y Manejo Agronómico de Plantas Injertadas en Jitomate. Master's Thesis, Universidad Autónoma de Chapingo, Chapingo, Mexico, May 2013. Available online: https: //chapingo.mx/horticultura/pdf/tesis/TESISMCH2013050810128186.pdf (accessed on 1 June 2018).

18. Leonardi, C.; Romano, D. Recent issues on vegetable grafting. Acta Hortic. 2004, 631, 163-174. [CrossRef]

19. Yang, S.; Xiang, G.; Zhang, S.; Lou, C. Electrical resistance as a measure of graft union. J. Plant Physiol. 1993, 141, 98-104. [CrossRef]

20. Bletsos, F.A.; Olympios, C.M. Rootstocks and Grafting of Tomatoes, Peppers and Egg plants for Soil-borne Disease Resistance, Improved Yield and Quality. Eur. J. Plant Sci. Biotechnol. 2008, 2, 62-73. Available online: http://www.globalsciencebooks.info/Online/GSBOnline/images/0812/EJPSB_2(SI1)/EJPSB_2(SI1)6273o.pdf (accessed on 1 June 2018).

21. Torii, T.; Kasiwazaki, M.; Okamoto, T.; Kitani, O. Evaluation of graft-take using a thermal camera. Acta Hortic. 1992, 319, 631-634. [CrossRef]

22. Oda, M.; Maruyama, M.; Mori, G. Water Transfer at Graft Union of Tomato Plants Grafted on to Solanum Rootstocks. J. Jpn. Soc. Hortic. Sci. 2005, 74, 458-463. [CrossRef]

23. De Miguel, A.; Cebolla, V. Terralia 53, Pages 50-60. Octubre 2005. Unión del Injerto. Available online: https://sci-hub.tw/http://hortsci.ashspublications.org/content/48/1/34.short (accessed on 5 May 2018).

24. Bausher, M.G. Road, South Rock, Pierce, Fort Graft Angle and Its Relationship to Tomato Plant Survival. Hort. Sci. 2013, 48, 34-36. Available online: http://hortsci.ashspublications.org/content/48/1/34.short (accessed on 6 June 2018).

25. Turquois, N.; Malone, M. Non-destructive assessment of developing hydraulic connections in the graft union of tomato. J. Exp. Bot. 1996, 47, 701-707. [CrossRef]

26. Xia, Y.; Sarafis, V.; Campbell, E.O.; Callaghan, P.T. Noninvasive imaging of water flow in plants by NMR microscopy. Protoplasma 1993, 173, 170-176. [CrossRef]

27. Hochmuth, R.; Davis, L.L.; Laughlin, W.L.; Simonne, E.H. Evaluation of Organic Nutrient Sources in the Production of Greenhouse Hydroponic Basil; Research Report 2003-08; University of Florida: Gainesville, FL, USA, June 2008; pp. 1-7.

28. Goh, K.M. Evaluation of potting media for commercial nursery production of container-grown plants. V. Patterns of release of nitrogen fertilizers in different media. N. Z. J. Agr. Res. 1979, 22, 163-171. [CrossRef]

29. Agricultural Statistics of Pakistan, 2017-2018. Available online: http://www.finance.gov.pk/survey/chapters_ 14/ (accessed on 1 December 2018).

30. Oda, M. Grafting of Vegetable Crops; Scientific Report of Agriculture and Biological Sciences; Osaka Prefecture University: Osaka, Japan, 2002; Volume 54, pp. 49-72.

31. Davis, A.R.; Perkins-Veazie, P.; Sakata, Y.; López-Galarza, S.; Maroto, J.V.; Lee, S.G.; Huh, Y.C.; Sun, Z.; Miguel, A.; King, S.R.; et al. Cucurbit grafting. Criti. Rev. Plant Sci. 2008, 27, 50-74. [CrossRef]

32. Sakata, Y.; Ohara, T.; Sugiyama, M. The history of melon and cucumber grafting in Japan. Acta Hortic. 2008, 767, 217-228. [CrossRef] 
33. Ito, T. Present state of transplant production practices in Japanese horticultural industry. In Proceedings of the International Symposiumon Transplant Production Systems, Transplantant Production Systems, Yokohama, Japan, 21-26 July 1992; Kurata, K., Kozai, T., Eds.; Kluwer Academic Publishers: Amsterdam, The Netherlands, 1992.

34. Kurata, K.; Kozai, T. Transplant Production Systems. In Proceedings of the International Symposium on Transplant Production Systems, Yokohama, Japan, 21-26 July 1992; Kluwer Academic Publishers: Dordrecht, The Netherlands; Boston, MA, USA; London, UK; p. 335. Available online: http://www.springer.com/us/ book/9780792317975 (accessed on 15 September 2018).

35. Lee, J.M.; Oda, M. Grafting of Herbaceous Vegetable and Ornamental Crops. In Horticulture Reviews; Janick, J., Ed.; John Wiley \& Sons: Hoboken, NJ, USA, 2003; Volume 28, p. 453.

36. Nishiura, Y.; Murase, H.; Honami, N.; Taira, T. Development of Plug-in Grafting Robotic System Osaka Prefecture University. In Proceedings of the IEEE International Conference on Robotics and Automaton, Nagoya, Japan, 25-27 May 1995; pp. 2510-2517. Available online: http://ieeexplore.iee.org/abstract/ document/525636/ (accessed on 19 September 2018).

37. Oda, M. Grafting of Vegetable Crops; Osaka Prefecture University: Osaka, Japan, March 2002; Volume 54, pp. 49-72. Available online: http://repository.osakafu-u.ac.jp/dspace/bitstream/10466/1053/1/KJ00000052064. pdf (accessed on 22 June 2018).

38. Oda, M. Use of Grafted Seedlings for Vegetable Production in Japan. Acta Hortic. 2008, 770, 15-20. [CrossRef]

39. Lee, J.M.; Bang, H.J.; Ham, H.S. Grafting of Vegetables. Jpn. Soc. Agric. Mach. Food Eng. 1998, 67, 1098-1104. Available online: https://www.jstage.jst.go.jp/article/jjshs1925/67/6/67_6_1098/_pdf (accessed on 22 June 2018). [CrossRef]

40. Pavlou, G.; Vakalounakis, D.; Ligoxigakis, E. Control of root and stem rot of cucumber, caused by Fusarium oxysporum f. sp. radicis-cucumerinum, by grafting onto resistant rootstocks. Plant Dis. 2002, 86, 379-382. [CrossRef]

41. Huang, Y.; Tang, R.; Cao, Q.; Bie, Z. Improving the fruit yield and quality of cucumber by grafting onto the salt tolerant rootstock under $\mathrm{NaCl}$ stress. Sci. Hortic. 1999, 122, 26-31. [CrossRef]

42. Cansev, A.; Ozgur, M. Grafting cucumber seedlings on Cucurbita spp.: comparison of different grafting methods, scions and their performance. J. Food Agric. Environ. 2010, 8, 804-809.

43. Uysal, N.; Tuzel, Y.; Oztekin, G.B.; Tuzel, I.H. Effects of different rootstocks on greenhouse cucumber production. Acta Hortic. 2012, 927, 281-289. [CrossRef]

44. Moradipour, F.; Dashti, F.; Zahedi, B. Effect of grafting on yield and some vegetative characteristics of two greenhouse cucumber cultivar. Iran. J. Hortic. Sci. 2010, 41, 291-300.

45. Hoyos, P. Influence of different rootstocks on the yield and quality of greenhouses grown cucumbers. Acta Hortic. 2001, 559, 139-143. [CrossRef]

46. Lee, J.; Bang, H.; Ham, H. Quality of cucumber fruit as affected by rootstock. Acta Hortic. 1999, 483, 117-124. [CrossRef]

47. Sakata, Y.; Ohara, T.; Sugiyama, M. The history and present state of the grafting of Cucurbitaceous vegetables in Japan. Acta Hortic. 2007, 731, 159-170. [CrossRef]

48. Davis, A.R.; Perkins-Veazie, P.; Hassell, R.; Levi, A.; King, S.R.; Zhang, X. Grafting effects on vegetable quality. HortScience 2008, 43, 1670-1672. [CrossRef]

49. Sonneveld, C. Estimating quantities of water-soluble nutrients using a specific 1:2 by volume extract. Soil Sci. Plant Anal. 1990, 21, 1257-1265. [CrossRef]

50. Oda, M. Grafting of Vegetables to Improve Greenhouse Production; Extension Bulletin 480; Food and Fertilizer Technology Center: Taipei city, China, 1 December 1999; p. 11.

51. Ishibashi, K. Tongue-approach grafting in cucurbits. Agr. Hort. 1965, 40, 1899-1902. (In Japanese)

52. Lee, J.M.; Oda, M. Grafting of herbaceous vegetable and ornamental crops. In Horticultural Reviews; Janick, J., Ed.; John Wiley and Sons: New York, NY, USA, 2003; Volume 28, pp. 61-124.

53. Davis, R.F. Effect of Meloidogyne incognita on watermelon yield. Nematropica 2007, 37, 287-293.

54. Yadava, I.L. A rapid and nondestructive method to determine chlorophyll in intact leaves. HortScience 1986, 21, 1449.

55. Association of Official Analytical Chemists. Official Methods of Analysis of the Association of Official Agriculture Chemists, 12th ed.; Association of Official Agricultural Chemists: Washington, DC, USA, 1975; p. 870. 
56. Ranganna, S. Manual of Analysis of Fruit and Vegetable Products; Tata McGraw-Hill Publishing: New Delhi, India, 1977; Volume 6, pp. 151-160.

57. Özarslandan, A.; Söğüt, M.A.; Yetișir, H.; Elekcığlu, I.H. Screening of bottle gourds (Lagenaria siceraria (Molina) Standley) genotypes with rootstock potential for watermelon production for resistance against Meloidogyne incognita (Kofoid \& White, 1919) Chitwood and Meloidogyne javanica (Treub, 1885) Chitwood. Turk. Entomol. Derg. 2011, 35, 687-697.

58. Ioannou, N. Integrating soil solarization with grafting on resistant rootstocks for management of soil-borne pathogens of eggplant. J. Hortic. Sci. Biotechnol. 2001, 7, 396-401. [CrossRef]

59. Salata, A.C.; Bertolini, E.V.; Magro, F.O.; Cardoso, A.; Wilcken, S.R.S. Effect of grafting on cucumber production and reproduction of Meloidogyne javanica and M. incognita. Hortic Bras. 2012, 30, 590-594. [CrossRef]

60. Netscher, C.; Sikora, R.A. Nematode parasites of vegetables. In Plant Parasitic Nematodes in Subtropical and Tropical Agriculture; CAB International: Wallingford, UK, 1990; pp. 237-283.

61. Walters, S.A.; Wehner, T.C. 'Lucia', 'Manteo', and 'Shelby' root-knot nematode-resistant cucumber inbred lines. HortScience 1997, 32, 1301-1303. [CrossRef]

62. Chen, Z.D.; Wand, P.S.; Zhou, Y.; Ji, Y.L.; Wan, Z.J.; Peng, L. Effects of rootstock grafting on yield, quality and control of Meloidogyne incognita of cucumber (Cucumis sativus L.). China Veget. 2012, 8, 57-62.

63. Miguel, A.; Maroto, J.V. El injerto herbáceo en la sandía (Citrullus lanatus) como alternativa a la desinfecció n química del suelo. Invest. Agrar. Prod. Prot. Veg. 1996, 11, 239-253.

64. Zhu, J.; Bie, Z.L.; Huang, Y.; Han, X.X. Effect of grafting on the growth and ion concentrations of cucumber seedlings under $\mathrm{NaCl}$ stress. Soil Sci. Plant Nutr. 2008, 54, 895-902. [CrossRef]

65. Zhong, Y.Q.; Bie, Z.L. Effects of grafting on the growth and quality of cucumber fruits. Acta Hortic. 2007, 761, 341-347. [CrossRef]

66. Yetisir, H.; Sari, N. Effect of different rootstock on plant growth, yield and quality of watermelon. Aust. J. Exp. Agric. 2003, 43, 1269-1274. [CrossRef]

67. Huang, Y.; Bie, Z.L.; Liu, Z.X.; Zhen, A.; Wang, W.J. Protective role of proline against salt stress is partially related to the improvement of water status and peroxidase enzyme activity in cucumber. Soil Sci. Plant Nutr. 2009, 55, 698-704. [CrossRef]

68. Aloni, B.; Cohen, R.; Karni, L.; Aktas, H.; Edelstein, H. Hormonal signaling in rootstock-scion interactions. Sci Hortic. 2010, 127, 119-126. [CrossRef]

69. Zhang, J.; Shu, W.S. Mechanisms of heavy metal cadmium tolerance in plants. J. Plant. Physiol. Mol. Biol. 2006, 32, 1-8.

70. Salehi-Mohammadi, R.; Khasi, A.; Lee, S.G.; Huh, Y.C.; Lee, J.M.; Delshad, M. Assessing survival and growth performance of Iranian melon to grafting onto Cucurbita rootstocks. Korean J. Hortic. Sci. Technol. 2009, 27, 1-6.

71. Hartmann, H.T.; Kester, D.E.; Davies, F.T.; Geneve, R.L. Plant Propagation: Principles and Practices; Prentice Hall: Upper Saddle River, NJ, USA, 1997; p. 770.

72. Martínez-Ballesta, M.C.; Alcaraz-López, C.; Muries, B.; Mota-Cadenas, C.; Carvajal, M. Physiological aspects of rootstock-scion interactions. Sci. Hortic. 2010, 127, 112-118. [CrossRef]

73. Molnar, A.; Melnyk, C.W.; Bassett, A.; Hardcastle, T.J.; Dunn, R.; Baulcombe, D.C. Small silencing RNAs in plants are mobile and direct epigenetic modification in recipient cells. Science 2010, 328, 872-875. [CrossRef] [PubMed]

74. Dunoyer, P.; Brosnan, C.A.; Schott, G.; Wang, Y.; Jay, F.; Alioua, A.; Himber, C.; Voinnet, O. An endogenous, systemic RNAi pathway in plants. Embryol. J. 2010, 29, 1699-1712. [CrossRef]

75. Harada, T. Grafting and RNA transport via phloem tissue in horticultural plants. Sci. Hortic. 2010, 125, 545-550. [CrossRef]

76. Yamasaki, A.; Yamashita, M.; Furuya, S. Mineral concentrations and cytokinin activity in the xylem exudates of grafted watermelons as affected by rootstocks and crop load. J. Jpn. Soc. Hortic. Sci. 1994, 62, 817-826. [CrossRef]

77. Zekri, M. Citrus rootstocks affect scion nutrition, fruit quality, growth, yield and economical return. Fruits 2000, 55, 231-239. [CrossRef]

78. Economides, C.V.; Gregoriou, C. Growth, yield and fruit quality of nucellar frost 'Marsh' Grapefruit on fifteen rootstocks in Cyprus. J. Amer. Soc. Hort. 1993, 118, 326-329. [CrossRef] 
79. Al-Jaleel, A.; Zekri, M.; Hammam, Y. Yield, fruit quality, and tree health of 'Allen Eureka' lemon on seven rootstocks in Saudi Arabia. Sci. Hort. 2005, 105, 457-465. [CrossRef]

80. Reddy, Y.T.N.; Kurian, R.M.; Ramachander, P.R.; Singh, G.; Kohli, R.R. Long-term effects of rootstocks on growth and fruit yielding patterns of 'Alphonso' mango (Mangifera indica L.). Sci. Hort. 2003, 97, 95-108. [CrossRef]

81. Traka-Mavronaa, E.; Metaxia, K.S.M.; Pritsaa, T. Response of squash (Cucurbita spp.) as rootstock for melon (Cucumis melo L.). Sci. Hort. 2000, 83, 353-362.

(C) 2019 by the authors. Licensee MDPI, Basel, Switzerland. This article is an open access article distributed under the terms and conditions of the Creative Commons Attribution (CC BY) license (http://creativecommons.org/licenses/by/4.0/). 